University of Montana

ScholarWorks at University of Montana

Chemistry and Biochemistry Faculty

Publications

Chemistry and Biochemistry

$9-9-2013$

\title{
Laboratory Characterization of PM Emissions from Combustion of Wildland Biomass Fuels
}

\author{
S. Hosseini \\ University of California - Riverside \\ S. P. Urbanski \\ USDA Forest Service - Rocky Mountain Research Station \\ P. Dixit \\ University of California - Riverside \\ L. Qi \\ University of California - Riverside \\ I. R. Burling \\ University of Montana - Missoula \\ See next page for additional authors
}

Follow this and additional works at: https://scholarworks.umt.edu/chem_pubs

Part of the Biochemistry Commons, and the Chemistry Commons

Let us know how access to this document benefits you.

\section{Recommended Citation}

Hosseini, S., et al. (2013), Laboratory characterization of PM emissions from combustion of wildland biomass fuels, J. Geophys. Res. Atmos., 118, 9914-9929, doi:10.1002/jgrd.50481.

This Article is brought to you for free and open access by the Chemistry and Biochemistry at ScholarWorks at University of Montana. It has been accepted for inclusion in Chemistry and Biochemistry Faculty Publications by an authorized administrator of ScholarWorks at University of Montana. For more information, please contact

scholarworks@mso.umt.edu. 


\section{Authors}

S. Hosseini, S. P. Urbanski, P. Dixit, L. Qi, I. R. Burling, Robert J. Yokelson, T. J. Johnson, M. Shrivastava, H. S. Jung, D. R. Weise, J. W. Miller, and D. R. Cocker III 


\title{
Laboratory characterization of PM emissions from combustion of wildland biomass fuels
}

\author{
S. Hosseini, ${ }^{1}$ S. P. Urbanski, ${ }^{2}$ P. Dixit, ${ }^{1}$ L. Qi, ${ }^{1,3}$ I. R. Burling, ${ }^{4}$ R. J. Yokelson, ${ }^{4}$ T. J. Johnson, ${ }^{5}$ \\ M. Shrivastava, ${ }^{5}$ H. S. Jung, ${ }^{1}$ D. R. Weise, ${ }^{6}$ J. W. Miller, ${ }^{1}$ and D. R. Cocker III ${ }^{1}$ \\ Received 27 September 2012; revised 30 April 2013; accepted 6 May 2013; published 9 September 2013.
}

[1] Particle emissions from open burning of southwestern (SW) and southeastern (SE) U.S. fuel types during 77 controlled laboratory burns are presented. The fuels include SW vegetation types: ceanothus, chamise/scrub oak, coastal sage scrub, California sagebrush, manzanita, maritime chaparral, masticated mesquite, oak savanna, and oak woodland, as well as SE vegetation types: 1 year, 2 year rough, pocosin, chipped understory, understory hardwood, and pine litter. The SW fuels burned at higher modified combustion efficiency (MCE) than the SE fuels resulting in lower particulate matter mass emission factor. Particle mass distributions for six fuels and particle number emission for all fuels are reported. Excellent mass closure (slope $\left.=1.00, r^{2}=0.94\right)$ between ions, metals, and carbon with total weight was obtained. Organic carbon emission factors inversely correlated $\left(R^{2}=0.72\right)$ with average MCE, while elemental carbon (EC) had little correlation with average MCE $\left(R^{2}=0.10\right)$. The EC/total carbon ratio sharply increased with MCE for MCEs exceeding 0.94. The average levoglucosan and total polycyclic aromatic hydrocarbon $(\mathrm{PAH})$ emissions factors ranged from 25 to $1272 \mathrm{mg} / \mathrm{kg}$ fuel and 1.8 to $11.3 \mathrm{mg} / \mathrm{kg}$ fuel, respectively. No correlation between average MCE and emissions of PAHs/levoglucosan was found. Additionally, PAH diagnostic ratios were observed to be poor indicators of biomass burning. Large fuel type and regional dependency were observed in the emission rates of ammonium, nitrate, chloride, sodium, and potassium.

Citation: Hosseini, S., et al. (2013), Laboratory characterization of PM emissions from combustion of wildland biomass fuels, J. Geophys. Res. Atmos., 118, 9914-9929, doi:10.1002/jgrd.50481.

\section{Introduction}

[2] Fresh smoke from wildland biomass burning is a complex mixture of gases and aerosol. The amount and composition of fire emissions depend on a wide range of parameters including fuel type, packing ratio, fuel composition, chemical composition, fuel moisture, and fire behavior (e.g., relative amounts of smoldering and flaming) [Andreae and Merlet, 2001; Akagi et al., 2011]. While

Additional supporting information may be found in the online version of this article.

${ }^{1}$ Bourns College of Engineering, University of California, Riverside, California, USA.

${ }^{2}$ Fire Sciences Laboratory, Rocky Mountain Research Station, USDA Forest Service, Missoula, Montana, USA.

${ }^{3}$ National Research Center for Environmental Analysis and Measurement, Beijing, China.

${ }^{4}$ Department of Chemistry, University of Montana, Missoula, Montana, USA.

${ }^{5}$ Pacific Northwest National Laboratories, Richland, Washington, USA

${ }^{6}$ Forest Fire Laboratory, Pacific Southwest Research Station, USDA Forest Service, Riverside, California, USA.

Corresponding author: D. Cocker, Bourns College of Engineering, University of California, 1084 Columbia Ave., Riverside, CA 92507, USA. (dcocker@engr.ucr.edu)

(C)2013. American Geophysical Union. All Rights Reserved. 2169-897X/13/10.1002/jgrd.50481 wildland fuels are composed primarily of cellulose, hemicelluloses, and lignin, the composition and quantity of trace elements vary by plant species, soil type, ambient air mass, sea-salt deposition, and anthropogenic nitrogen and sulfur deposition [Albini, 1976; Fenn, 1991; Hardy et al., 1996; McKenzie et al., 1996; Yokelson et al., 2011]. Local climate and meteorological conditions influence both plant structure and moisture-conserving strategies, which in turn influence fire behavior and smoke emissions when these fuel types are burned.

[3] While the mean June-August temperatures are similar $\left(15-27^{\circ} \mathrm{C}\right)$, the southwestern (SW) United States tends to be drier (34-69 $\mathrm{cm}$ annual precipitation) than the more humid southeastern (SE) United States $(114-160 \mathrm{~cm})$ and the seasonality of precipitation is different $(23-30 \mathrm{~cm}$ December-February for both regions, $<3 \mathrm{~cm}$ and $30-42 \mathrm{~cm}$ June-August for the SW and SE, respectively. (Climatological statistics derived from data developed by National Climatic Data Center using U.S. Climate Division Dataset Mapping Page and 1981-2010 base period (http://www.esrl.noaa.gov/ psd/data/ usclimdivs/), accessed on 24 April 2012.) However, some plants and plant communities have developed similar structure and foliar characteristics such as chaparral in California and pocosin in North Carolina [Keeley, 2001]. Prescribed burning is a vegetation management tool used to manage wildlife habitat, remove wildland fuel accumulation 
to reduce the potential for severe wildfire, and mimic the natural role of fire [Chandler et al., 1983]. Recent modeling studies have analyzed the potential use of prescribed burning as a tool to reduce carbon dioxide emissions [Narayan et al., 2007; Wiedinmyer and Hurteau, 2010]. Due to a variety of reasons, prescribed burning is used extensively in the SE in contrast to limited use in chaparral and oak ecosystems in the SW. Between 2002 and 2011, the annual average area treated with prescribed burning was 599,000 ha in the southeastern U.S. (SE: Alabama, Arkansas, Florida, Georgia, Louisiana, Mississippi, North Carolina, South Carolina, Tennessee, and Virginia) and 134,000 ha in the southwestern U.S. (SW: Arizona, California, Colorado, New Mexico, Nevada, and Utah) (National Interagency Fire Center http://www. nifc.gov/, accessed on June 14, 2012. During the same

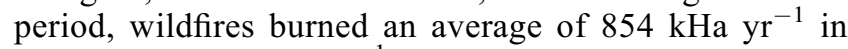
the SW and $215 \mathrm{kHa} \mathrm{yr}^{-1}$ in the SE (NIFC, 2012).

[4] While prescribed burning is an important land management tool, emissions from prescribed fires and wildfires can have a significant detrimental impact on air quality by degrading visibility and increasing ambient concentrations of fine particulate matter $\left(\mathrm{PM}_{2.5}\right.$, aerosol with an aerodynamic diameter $\leq 2.5 \mu \mathrm{m})$ and ozone $\left(\mathrm{O}_{3}\right)$. More generally, emissions from biomass combustion can have a substantial influence on local-to-global scale chemical and physical properties of the atmosphere through short- and long-range transport [Crutzen and Andreae, 1990; Fishman et al., 1991]. Smoke aerosols can alter the radiation budget of the earth, cloud properties, and climate [Reid et al., 1998; Haywood et al., 2003; Kaufman and Fraser, 1997; Hobbs et al., 1997]. Epidemiological studies have linked mass concentration of $\mathrm{PM}_{2.5}$ to human morbidity and mortality [Pope et al., 2009]. Wildland firefighter exposure studies have reported exposures to $\mathrm{CO}$, particulates, and silica at levels near or higher than recommended occupational exposure levels [Materna et al., 1992]. Other studies report that smoke exposure occasionally approaches legal and recommended exposure levels [Reinhardt and Ottmar, 1997]. Because of the different nature of the work, firefighters generally were exposed to more smoke on prescribed fires than on wildfires [Reinhardt and Ottmar, 2004]. Additionally, toxic gases [Roberts et al., 2011] are emitted and several polycyclic aromatic hydrocarbons (PAHs) present in wood smoke are known to be carcinogenic and/or associated with mutagenicity [Roberts and Corkill, 1998; Ramdahl and Becher, 1982].

[5] Emissions from combustion of wildland fuels remain to be a significant source of uncertainty in regional and global emission estimates [Schultz et al., 2008; Wiedinmyer et al., 2006]. To lower these uncertainties, it is necessary to provide better characterized emissions and combustion parameters to emission inventory algorithms that provide emission input to transport and smoke dispersion models. This can be done through field and controlled laboratory studies. Field studies have the advantage of measuring emissions from an actual fire, although sampling time, sampling phase, and number of measured species are limited [e.g., Lee et al., 2005; Hardy et al., 1996; Hays et al., 2002; Muhle et al., 2007; Yokelson et al., 1999]. Controlled laboratory studies, on the other hand, can rectify these shortcomings of field studies [e.g., Chakrabarty et al., 2006; Chen et al., 2006, 2007, 2010; Hays et al., 2002]. Except for the study of McMeeking et al. [2009] that has three common fuels with this study, we are unaware of any other laboratory measurements of emissions from combustion of southwestern and southeastern U.S. plant species. Finally, very few studies have a comprehensive set of measurements [e.g., McMeeking et al., 2009] that include speciated particle-phase emissions, along with an indicator of combustion condition. To the best of our knowledge, no study prior to the current study has reported particle-phase PAHs and levoglucosan as extensively as the current study. Compared to McMeeking et al. [2009] that had 33 burns from SE fuels, we had 77 burns from SW and SE. We significantly increased the weight of the pile and characterized the particlephase inorganic content. The objective of our study is to determine particulate matter emission factor $(\mathrm{EF})$ for the combustion of fuels representative of ecosystems commonly managed with prescribed burning in SW and SE U.S. EF was determined by measuring particulate and gas phase emissions from the burning of fuels in the large-scale combustion facility at U.S. Forest Service (USFS) Missoula Fire Sciences Laboratory. The current study presents only a subset of results; the other results from lab and field components are published elsewhere [Burling et al., 2010, 2011; Hosseini et al., 2010; Veres et al., 2010; Roberts et al., 2010].

\section{Experimental Methods}

\subsection{Fuel Type Description}

[6] Samples of vegetation representing important wildland fuel types on Department of Defense installations in the SW and SE U.S. were harvested in the field and shipped to the U.S. Forest Service Fire Sciences Laboratory (FSL) in Missoula, Montana, in January 2009. These fuel types were typical for these two regions. The fuels were stored in their shipping boxes at ambient condition for January and then burned in the FSL combustion facility in February 2009, 3-5 weeks after harvest. In order to let the fuels lose moisture content, they were not placed in plastic bags.

[7] Table 1 describes the species composition and chemistry of vegetation comprising each fuel type studied and provides the three-letter fuel code used for fuel type in this paper. This list encompasses nine and four fuel types from the SW and SE, respectively, that were provided by the United States Forest Service (USFS). The fuel types in the current study, for most cases, are a mixture of two or more vegetation types or fuel components. For example, maritime chaparral (fuel code: $\mathrm{mch}$ ) is a mixture of Ceanothus impressus var. impressus, C. cuneatus var. fascicularis, and Salvia mellifera. Further details regarding the fuels are provided in Burling et al. [2010], Hosseini et al. [2010], and Yokelson et al. [2013].

[8] Fuels were analyzed for chemical composition by first grinding the plant tissues (wood and foliage) into a uniform coarse material using a Thomas Model 4 Wiley ${ }^{\circledR}$ Mill. (The use of trade names is provided for informational purposes only and does not constitute endorsement by the U.S. Department of Agriculture.) The samples were further ground to extremely fine particles using a mortar and pestle grinder. Approximately $5 \mathrm{~g}$ of each fuel sample was analyzed for $\mathrm{C}, \mathrm{H}, \mathrm{N}, \mathrm{S}$, and $\mathrm{O}$ using a combustion technique [McGeehan and Naylor, 1998] on a Thermo Fisher Scientific FlashEA 1112 Series Elemental Analyzer (Table 1). The vegetation components comprising the fuel beds were also analyzed by an outside laboratory (University of Idaho Analytical 
Table 1. Elemental Composition of Fuel Types Used in This Work and Summary of Fuel Types, Codes, and Number of Burns for Each Burn

\begin{tabular}{|c|c|c|c|c|c|c|c|c|c|c|c|c|}
\hline Fuel Type & $\begin{array}{l}\text { Fuel } \\
\text { Code }\end{array}$ & $\begin{array}{l}\text { No. of } \\
\text { Burns }\end{array}$ & $\begin{array}{c}\mathrm{N} \\
(\mathrm{wt} \%)\end{array}$ & $\begin{array}{c}\mathrm{C} \\
(\mathrm{wt} \%)\end{array}$ & $\begin{array}{c}\mathrm{S} \\
(\mathrm{wt} \%)\end{array}$ & $\begin{array}{c}\mathrm{O} \\
(\mathrm{wt} \%)\end{array}$ & $\begin{array}{c}\mathrm{H} \\
(\mathrm{wt} \%)\end{array}$ & $\begin{array}{c}\mathrm{Cl} \\
(\mathrm{wt} \%)\end{array}$ & $\begin{array}{c}\mathrm{K} \\
(\mathrm{wt} \%)\end{array}$ & $\begin{array}{c}\mathrm{Na} \\
(\mathrm{wt} \%)\end{array}$ & $\begin{array}{c}\text { Fuel Moisture } \\
(\%)\end{array}$ & $\begin{array}{c}\text { Burn Pile Weight } \\
(\mathrm{kg})\end{array}$ \\
\hline \multicolumn{13}{|c|}{ Southwestern Fuels } \\
\hline Ceanothus $^{\mathrm{a}}$ & cea & 6 & 1.05 & 43.46 & 0.01 & 42.34 & 6.04 & 0.2 & 0.4 & 0.05 & $8.2-10.5$ & $1.91-2.41$ \\
\hline Chamise/scrub oak ${ }^{\mathrm{b}}$ & chs & 6 & 0.92 & 47.49 & 0.00 & 41.17 & 6.60 & $<0.005$ & 0.11 & $<0.008$ & $6.3-16.5$ & $2.98-3.02$ \\
\hline California sage $\mathrm{e}^{\mathrm{c}}$ & cas & 6 & 1.12 & 48.11 & 0.22 & 40.59 & 6.69 & 0.3 & 1.1 & 0.16 & $7.8-9.8$ & $1.99-3.50$ \\
\hline Coastal sage ${ }^{\mathrm{d}}$ & $\cos$ & 5 & 1.00 & 47.92 & 0.44 & 41.90 & 6.66 & 0.3 & 0.69 & 0.41 & $8.5-8.9$ & $2.37-2.70$ \\
\hline Maritime chaparral $^{\mathrm{e}}$ & mch & 5 & 1.10 & 46.90 & 0.03 & 44.18 & 6.51 & 0.385 & 0.69 & 0.145 & $7.9-10.7$ & $3.05-3.66$ \\
\hline Manzanita ${ }^{f}$ & man & 6 & 1.00 & 41.33 & 0.20 & 42.07 & 5.74 & 0.058 & 0.42 & 0.046 & $7.5-13.5$ & $2.00-4.11$ \\
\hline Masticated mesquite ${ }^{g}$ & mes & 5 & 1.25 & 50.96 & 0.03 & 44.29 & 7.08 & 0.086 & 0.635 & $<0.008$ & $1.4-15.0$ & $1.19-2.13$ \\
\hline Oak savanna ${ }^{\mathrm{h}}$ & oas & 5 & 0.78 & 52.47 & 0.03 & 46.51 & 7.29 & 0.0053 & 0.28 & $<0.008$ & $8.7-13.4$ & $2.81-3.41$ \\
\hline Oak woodland $^{\mathrm{i}}$ & oaw & 5 & 0.59 & 43.40 & 0.00 & 43.31 & 6.03 & 0.011 & 0.47 & $<0.008$ & $10.4-15.0$ & $2.53-3.69$ \\
\hline \multicolumn{13}{|c|}{ Southeastern Fuels } \\
\hline 1 year herbaceous ${ }^{\mathrm{j}}$ & 1 year & 3 & 0.82 & 53.27 & 0.06 & 40.00 & 7.40 & 0.016 & 0.2 & 0.015 & $2.6-27.9$ & $0.25-0.91$ \\
\hline 2 year herbaceous ${ }^{\mathrm{j}}$ & 2 year & 4 & 1.07 & 49.68 & 0.10 & 39.55 & 6.90 & 0.032 & 0.25 & 0.03 & $19.6-31.5$ & $0.80-1.13$ \\
\hline $\begin{array}{l}\text { Chipped understory } \\
\text { hardwood }^{\mathrm{k}}\end{array}$ & cuh & 3 & $-{ }^{k}$ & - & - & - & - & - & - & - & $4.2-7.2$ & $2.48-3.24$ \\
\hline Understory hardwood ${ }^{1}$ & uh & 3 & - & - & - & - & - & - & - & - & $5.9-24.7$ & $1.48-3.24$ \\
\hline Pocosin ${ }^{\mathrm{j}}$ & poc & 3 & - & - & - & - & - & 0.028 & 0.12 & 0.012 & $6.6-22.5$ & $4.75-5.57$ \\
\hline Pine litter ${ }^{\mathrm{m}}$ & lit & 5 & 0.77 & 49.05 & 0.02 & 42.31 & 6.81 & 0.013 & 0.11 & $<0.008$ & $3.4-6.2$ & $0.96-1.56$ \\
\hline $\begin{array}{l}{ }^{\mathrm{a}} \text { Ceanothus leucoder } \\
{ }^{\mathrm{b}} \text { Adenostoma fascicu } \\
{ }^{\mathrm{c}} \text { Artemisia californic } \\
{ }^{\mathrm{d}} \text { Salvia mellifera, Er } \\
{ }^{\mathrm{e}} \text { Ceanothus impress } \\
{ }^{\mathrm{f}} \text { Arctostaphylos rudi } \\
{ }^{\mathrm{g}} \text { Prosopis velutina, } \\
{ }^{\mathrm{h}} \text { Quercus emoryi, Er } \\
{ }^{\mathrm{i}} \text { Quercus emoryi, Ar } \\
{ }^{\mathrm{j}} \text { Lyonia lucida, Ilex } \\
{ }^{\mathrm{k}} \text { Hyphen (-) indicate } \\
{ }^{1} \text { Acer rubrum, Perse } \\
{ }^{\mathrm{m}} \text { Pinus taeda, Pinus }\end{array}$ & $\begin{array}{l}\text { nis. } \\
\text { atum, } Q \\
\text { Erical } \\
\text { cameria } \\
\text { var. im } \\
\text { Arctos } \\
\text { acchari. } \\
\text { grostis } \\
\text { tostaphy } \\
\text { abra. } \\
\text { "not an } \\
\text { borbon } \\
\text { chinata }\end{array}$ & $\begin{array}{l}\text { lercus b } \\
\text { eria eric } \\
\text { ericoides } \\
\text { oressus, } \\
\text { aphylos } \\
\text { sarothro } \\
\text { ehmanni } \\
\text { os pung } \\
\text { lyzed". } \\
\text { a, Gardo }\end{array}$ & $\begin{array}{l}\text { rberidifo } \\
\text { oides. } \\
\text { Artemis } \\
\text { urissima } \\
\text { ides. } \\
\text { ina. } \\
\text { ns. }\end{array}$ & $\begin{array}{l}s \text { califor } \\
s \text { var. } f a\end{array}$ & $\begin{array}{l}\text { ca. } \\
\text { icular }\end{array}$ & alvia & llifera. & & & & & \\
\hline
\end{tabular}

Sciences Laboratory) for $\mathrm{Cl}, \mathrm{K}$, and Na content (Table 1). A $0.25 \mathrm{~g}$ dried ground plant tissue was digested in $3 \mathrm{~mL}$ of nitric acid for $6 \mathrm{~h}$ in $30^{\circ} \mathrm{C}$. Subsequently, the sample was analyzed using inductively coupled plasma atomic emission spectrometry (ICP-AES) method [Anderson, 1996] for concentrations of $\mathrm{K}$ and $\mathrm{Na}$ on a Perkin Elmer Optima 3200RL ICP-AES. Similarly, $0.5 \mathrm{~g}$ dried ground plant tissue was extracted using $0.01 \mathrm{~N}$ nitric acid, and then the chloride concentration was determined by ion chromatography on a Dionex DX-100 Ion Chromatograph (Dionex, USA). For anion separation, an IonPac AG4A-SC $4 \mathrm{~mm}$ guard column and an IonPac AS4A-SC $4 \mathrm{~mm}$ analytical column were used.

\subsection{Combustion Facility and Burn Procedure}

[9] Experiments were conducted at the U.S. Forest Service's combustion facility at the Fire Sciences Laboratory (FSL) in Missoula, Montana. The facility is a large air-conditioned chamber that measures $12.5 \mathrm{~m} \times 12.5 \mathrm{~m} \times 22 \mathrm{~m}$ in volume (Figure S1 in the supporting information). A $3.6 \mathrm{~m}$ inverted funnel opening approximately $2 \mathrm{~m}$ above the floor captures the smoke from fires on a continuously weighed fuel bed. The smoke is then directed through a $1.6 \mathrm{~m}$ diameter exhaust stack that exhausts through the ceiling. The room is pressurized slightly to ensure complete entrainment of fire emissions. A large sampling platform surrounds the stack at $17 \mathrm{~m}$ elevation where an open-path Fourier transform infrared spectrometer (OP-FTIR) and a suite of particle instrumentation were located (Figure 1). The smoke at the height of sampling platform is well mixed and has the same temperature and mixing ratios across the stack diameter [Christian et al., 2003, 2004].
[10] The fuel bed was an aluminum frame with wire mesh and removable heat-resistant $1.27 \mathrm{~cm}$ Kaowool M Board that was removed depending on the physical characteristics of the vegetation. Two electronic balances continuously recorded the mass of the fuel. The air speed in the stack was 1.5 and $3.0 \mathrm{~m} / \mathrm{s}$ for majority of the burns. Nearly all of the fires were ignited with a propane torch; a small number were ignited using isopropyl alcohol in addition to the torch. Additional information on the FSL combustion facility may be found in Christian et al. [2004].

\subsection{Measurement System and Sample Analysis}

[11] In addition to the sampler system demonstrated in Figure 1, several particulate-phase instruments were also located on the platform: an Aerodyne High Resolution Time of Flight Aerosol Mass Spectrometer (HR-TOF-AMS, Aerodyne Inc.), an Ultrafine Condensation Particle Counter (UCPC Model 3776, TSI Inc.), a Scanning Mobility Particle Sizer (SMPS), a Fast Mobility Particle Sizer (FMPS Model 3091, TSI Inc.), an Aerodynamic Particle Sizer (APS Model 3321, TSI Inc.), a Micro-Orifice Uniform Deposit Impactor (MOUDI, MSP Corp.), and a Dekati ${ }^{\circledR}$ Mass Monitor (DMM) [Mamakos et al., 2006].

[12] A single $1.0 \mathrm{~cm} \times 1.5 \mathrm{~cm}$ punch from each quartz filter was analyzed for elemental and organic carbon (EC/OC) by both University of California, Riverside and the USFS with a Sunset Laboratory (Forest Grove, Oregon) Thermal/Optical Analyzer following the National Institute for Occupational Safety and Health (NIOSH) 5040 reference method (1996) [Birch and Cary, 1996]. The final OC concentrations were estimated by subtracting the OC measured on the backup filters 


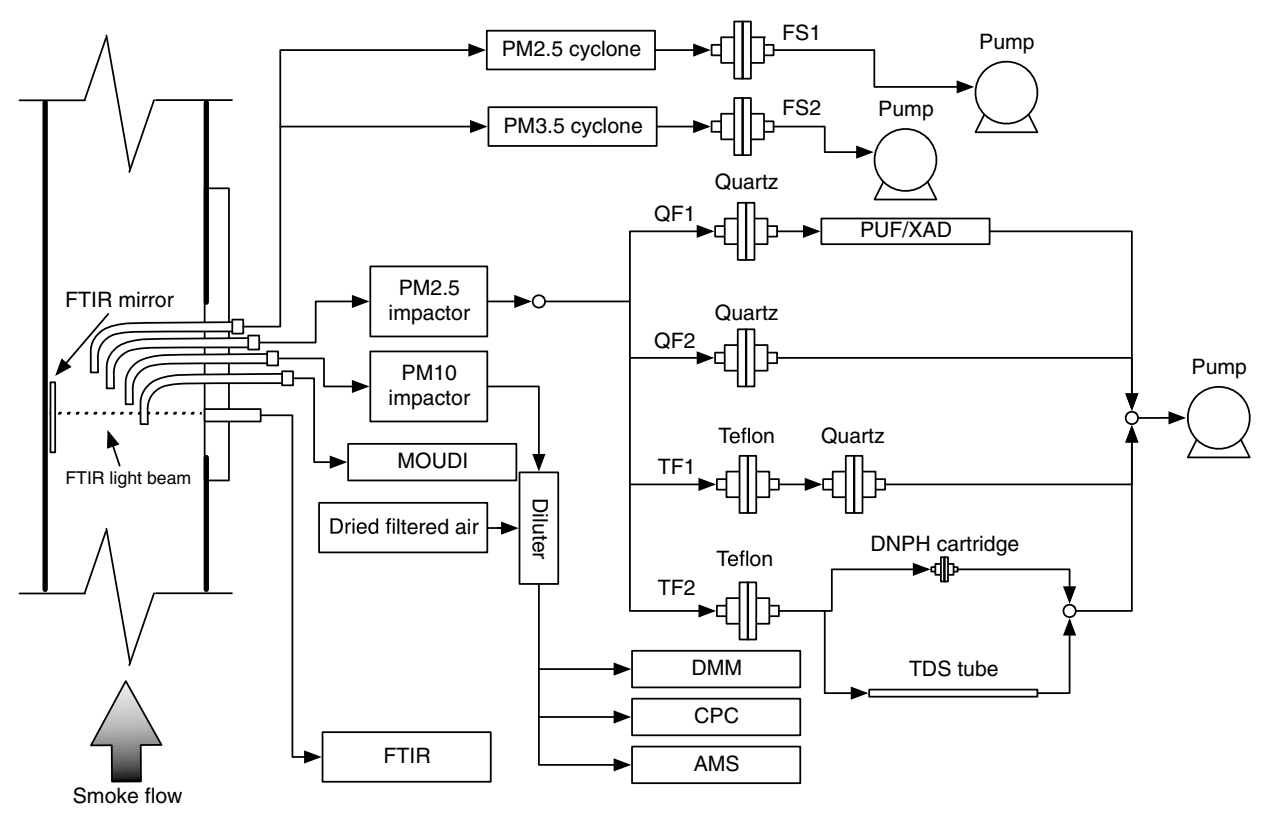

Figure 1. Schematic graph of the sampling system used to measure the emissions; a $\mathrm{PM}_{2.5}$ impactor was applied before the filter sampler system, and a $\mathrm{PM}_{10}$ impactor was used for other instruments.

from the $\mathrm{OC}$ measured on the front filters according to $\mathrm{Na}$ et al. [2004]. Pre-experiment and post-experiment Teflon filter weights were obtained following the Code of Federal Regulations (40CFR Part 1065, Washington, D. C., 2005).

[13] Following gravimetric analysis, elemental composition of the deposited material on the Teflon filters was determined using X-ray fluorescence (XRF). The USFS samples were analyzed by Chester Labnet (Tigard, Oregon) using U.S. Environmental Protection Agency Method IO-3.3. The UCR samples were analyzed by the South Coast Air Quality Management District (SCAQMD, Diamond Bar, California) using an Energy Dispersion X-Ray Fluorescence (EDXRF) spectrometer (Epsilon $5^{\circledR}$, PANalytical, Netherlands) equipped with dual anode (scandium/tungsten) X-ray tube. Each filter was analyzed 10 separate times using 10 different excitation conditions under vacuum. The instrument software deconvoluted and calculated the concentration for each element in $\mu \mathrm{g} / \mathrm{m}^{3}$. For the EDXRF technique, analytical quality control was determined by testing the National Institute of Standards and Technology Standard Reference Material 2783. Most USFS Teflon filters were analyzed by XRF method for 29 burns, while UCR analyzed one filter for each fuel type.

[14] A set of $47 \mathrm{~mm}$ Teflon substrates was used for Ion Chromatography (IC) analysis following California Air Resources Board Method MLD 142 [California Air Resources Board, 2011]. The filters were uniformly wetted using approximately $1 \mathrm{~mL}$ of isopropyl alcohol and subsequently extracted into $5 \mathrm{~mL}$ of de-ionized water by a $20 \mathrm{~min}$ sonication process. Aliquots of the extract were then filtered and analyzed on a Dionex DX-120 ion chromatograph. The analysis yielded concentrations of the following ions: sulfate, nitrite, chloride, bromide, sodium, ammonium, potassium, and calcium.

[15] The $47 \mathrm{~mm}$ quartz substrates were spiked with ${ }^{13} \mathrm{C}$ labeled levoglucosan (purchased from Cambridge Isotope Laboratories Inc., Andover, Massachusetts) and select deuterated PAHs. The ${ }^{13} \mathrm{C}$ spike volume was calculated based on the real-time slope of levoglucosan versus OC determined by the HR-TOF-AMS for each filter, whereas the PAH spike volume was maintained constant at $100 \mu \mathrm{L}$ on each filter. The filters were extracted using a 50:50 solvent mixture of dichloromethane and acetone by a Dionex ${ }^{\circledR}$ Accelerated Solvent Extractor 200 (ASE). A total volume of $21 \mathrm{~mL}$ was obtained for each filter. Half of the extracted volume was used for levoglucosan analysis and the other half for the PAH analysis.

[16] The half of the extracted sample used for PAH analysis was concentrated to $5 \mathrm{~mL}$ by rotary evaporation using a BUCHI-3000 evaporator. The sample was further concentrated to $1.5 \mathrm{~mL}$ with a nitrogen stream. This final volume was transferred to amber wide crimp top vials, sealed, and analyzed on an Agilent ${ }^{\circledR} 6890$ GC-5973 MSD equipped with a Programmable Temperature Vaporizer (PTV) large volume inlet (7683 Series).

[17] The other half of the extracted sample was concentrated to $5 \mathrm{~mL}$ by rotary evaporation using a Buchi ${ }^{\circledR}$ R-3000 Rotary evaporator. This sample was further evaporated to $250 \mu \mathrm{L}$ aliquot under a stream of nitrogen. Fifty microliters of the aliquot was transferred into an amber vial and dried under a nitrogen stream. The sample was then derivatized for $2 \mathrm{~h}$ at $70^{\circ} \mathrm{C}$ with $50 \mu \mathrm{L}$ of N,O-bis(trimethylsilyl) trifluoroacetamide and $25 \mu \mathrm{L}$ of pyridine (obtained from Sigma-Aldrich Chemie $\mathrm{GmbH}$, Switzerland). The sample was subsequently re-diluted to a specific calculated volume based on expected LG concentration, transferred to an amber wide crimp top vial, sealed, and analyzed on a gas chromatography-mass spectrometer (GC-MS). Complete silylation of levoglucosan was confirmed by the absence of partially silylated derivatives measured by GC-MS. The mass spectrum of levoglucosan tritrimethylsilyl ether exhibited only a small molecular ion $(\mathrm{m} / \mathrm{z} 378)$ with fragments due to loss of $\mathrm{CH}_{3}(\mathrm{~m} / \mathrm{z} 363), \mathrm{CH}_{5} \mathrm{Si}(\mathrm{m} / \mathrm{z} 333)$, $\mathrm{C}_{6} \mathrm{H}_{17} \mathrm{OSi}_{2}(m / z 217)$, and $\mathrm{C}_{7} \mathrm{H}_{18} \mathrm{OSi}_{2}$ ( $m / z$ 204, base peak). Fragments 217 and 333 were used for quantification. 
Table 2. Emission Factors of Total $\mathrm{PM}_{2.5}, \mathrm{EC}, \mathrm{OC}, \mathrm{K}, \mathrm{Cl}, \mathrm{Na}$, and $\mathrm{S}$ in $\mathrm{g} / \mathrm{kg}$ Fuel Burned and EC/TC Ratio ${ }^{\mathrm{a}}$

\begin{tabular}{|c|c|c|c|c|c|c|c|c|c|}
\hline Spec & MCE & $\mathrm{EC} / \mathrm{TC}$ & $\mathrm{PM}_{2.5}$ & $\mathrm{EC}$ & $\mathrm{OC}$ & K & $\mathrm{Cl}$ & $\mathrm{Na}$ & $\mathrm{S}$ \\
\hline \multicolumn{10}{|c|}{ Southwest } \\
\hline $\mathrm{a} / \mathrm{FHL}$ & $0.953(0.008)$ & 40 & $4.62(2.0$ & $.64(0.29)$ & $1.16(0$ & $0.607(0.065)$ & $0.345(0.034)$ & $0.016(0.011)$ & $.025(0.004)$ \\
\hline & 1) & & & $6(0$ & 2.18( & 5) & 8) & 4) & 31) \\
\hline FB & 4) & 7) & 3) & 4) & 1.16( & 57) & 15) & 14) & $01)$ \\
\hline $\mathrm{FB}$ & $39(0$ & $62(0$ & $6.36(0.72)$ & $4(0.17)$ & $0.97(0$ & $664(0.575)$ & $85(0.509)$ & $169(0.239)$ & $053(0.046)$ \\
\hline & $948(0.007)$ & $42(0.14)$ & $3.61(1.17)$ & $0.51(0.18)$ & $0.85(0.71)$ & $0.525(0.061)$ & $0.323(0.063)$ & $.218(0.043)$ & $.044(0.007)$ \\
\hline & & & & & & & & & \\
\hline Chape & 0) & & 5.461 & & & & b) & 9) & \\
\hline m & $00=10$ & 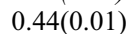 & $2.97(0$ & ) & 0.7 & 3) & & 0 . & \\
\hline oas/FHUA & 071 (1004 & $0.52(0.08)$ & $1.61(0.38)$ & $050 \%$ & $0.44(0$ & $0.169(0.039)$ & $0.048(0.013)$ & $0.005(0$. & $0.027(0.009)$ \\
\hline oaw/1 & $x=c 0$ & te & 2.01( & - & 0.67 & & $0.026(0$ & 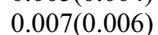 & $0.029(0.020)$ \\
\hline FHUA & $.963(0.003)$ & .08) & +2) & $49(0.15)$ & 0.58 & $0.297(0.248)$ & $0.166(0.219)$ & $0.005(0.005)$ & $0.030(0.013)$ \\
\hline \multicolumn{10}{|c|}{ putheast } \\
\hline It/ $/ \mathrm{D}$ & & & & $.06(0.63)$ & 10.6 & & & & \\
\hline $11 \mathrm{yr} / \mathrm{CI}$ & . & 0.08 & 11.3 & $0.46(0.17)$ & & & & 20) & 13) \\
\hline $2 \mathrm{yr} / \mathrm{CL}$ & & & & & & & & & \\
\hline & & & & $0.44(\mathrm{C}$ & 0.0 & & & & ( \\
\hline & & & & & & & & & (1) \\
\hline uh/CL & $.954(0.0$ & $0.32(\mathrm{C}$ & $7.46(2$. & $1.51(0$ & 3.0 & $0.282(0.0$ & $0.095(0.025)$ & $0.046(0.009)$ & $0.047(0.015)$ \\
\hline Camp Lejeune ave. & $0.938(0.008)$ & $0.17(0.06)$ & $10.79(4.12)$ & $0.81(0.37)$ & $5.66(1.85)$ & $0.172(0.136)$ & $0.060(0.045)$ & $0.047(0.037)$ & $0.029(0.017)$ \\
\hline
\end{tabular}

${ }^{\mathrm{a}}$ Numbers in parentheses represent one standard deviation. The acronym after fuel name represents the location the fuel was collected from-FHL: Fort Hunter Liggett; VAFB: Vandenberg Air Force Base; FHUA: Fort Huachuca; FB: Fort Benning; CL: Camp Lejeune.

[18] The general fire behavior (i.e., the relative amount of flaming and smoldering combustion) was characterized using modified combustion efficiency (MCE) based on $\mathrm{CO}$ and $\mathrm{CO}_{2}$ concentrations measured by OP-FTIR (further details in Burling et al. [2010]). The MCE is defined as the fire-integrated excess ratio of $\mathrm{CO}_{2}$ to $\mathrm{CO}$ plus $\mathrm{CO}_{2}$ $\left(\mathrm{MCE}=\frac{\Delta \mathrm{CO}_{2}}{\Delta \mathrm{CO}+\Delta \mathrm{CO}_{2}}\right) \quad[$ Ward and Radke, 1993]. It was assumed that the background concentrations of $\mathrm{CO}$ and $\mathrm{CO}_{2}$ were constant during the burns and were equal to their $1 \mathrm{~min}$ averaged concentration prior to ignition.

\section{Results and Discussion}

[19] Seventy-seven fuel beds were burned in an 18 day period in February 2009. Mean temperature and relative humidity in the facility during this period were $23.7^{\circ} \mathrm{C}$ (standard deviation $(\mathrm{SD})=2.0)$ and $15.2 \%(\mathrm{SD}=3.5)$, respectively. While in storage, the samples lost much of the moisture and were drier than living vegetation when normally burned during either a prescribed burn or wildfire. Moisture content of the SW fuels ranged from 1.4 to $16.5 \%$; moisture content in living chaparral ranges from 70 to $160 \%$ over the normal growing cycle [Countryman and Dean, 1979]. Similarly, moisture content of the SE fuels ranged from 2.6 to $31.5 \%$; moisture content in living evergreen pocosin shrubs ranged from about 70 to $250 \%$ [Blackmarr and Flanner, 1975]. The fuel arrangement significantly affected the fuel consumption. Initially, five chamise/scrub oak and three ceanothus fuel beds were arranged vertically; however, the fire failed to spread well resulting in low fuel consumptions of $3 \%$ to $52 \%$ (average: $26 \%$ ). The remaining fuel beds were arranged horizontally, which greatly increased fuel consumption to $\sim 90 \%$ for the rest of the burns. A total of 77 fires ( 71 from SE and SW fuel beds) were conducted at the Missoula FSL combustion facility in February 2009.
[20] The fuel content of $\mathrm{Cl}, \mathrm{K}$, and $\mathrm{Na}$ varied greatly with location of origin and plant type (see Table 1). Because we did not measure fuel consumption by vegetation component, we cannot quantitatively link element loss in the fuels to the particle and gas-phase emissions. However, we have estimated lower and upper limits on element release for each fuel type and aggregated these limits to provide a representative value for each location (see Table 1). The purpose of these representative values is to illuminate the role of fuel chemistry in aerosol element emissions; they are not intended for developing quantitative relationships.

\subsection{Determination of the Mix of Combustion Processes}

[21] Modified combustion efficiency (MCE) [Ward and Radke, 1993; Yokelson et al., 1996], calculated for each burn, was used to ascertain the relative amount of combustion processes (e.g., smoldering and flaming; average MCE is shown in Table 2). The average of fire-integrated MCE values for all burns is 0.94 with one standard deviation of 0.02 (median: 0.94; range: 0.87-0.98) indicating that all the burns had a mix of flaming and smoldering with high MCE indicating relatively more flaming. The coefficient of variation of MCE for all the burns in this study is smaller than some previous studies (e.g., $2.1 \%$ versus $3.1 \%$ of McMeeking et al. [2009]).

\subsection{Fuel Moisture (FM) Versus MCE}

[22] Moisture content can affect emission factors by lowering their modified combustion efficiency (MCE). Wetter fuels smolder more while drier fuels burn more completely. Fuels as found in their habitat usually have $>30 \% \mathrm{FM}$; however, this biomass is difficult to burn in the laboratory. Further, during a typical prescribed burn/ wildland fire, the fire front reduces fuel FM prior to combustion. Therefore, the actual FM at time of burning depends on initial FM as well as the radiation intensity and size of the surrounding fire. 


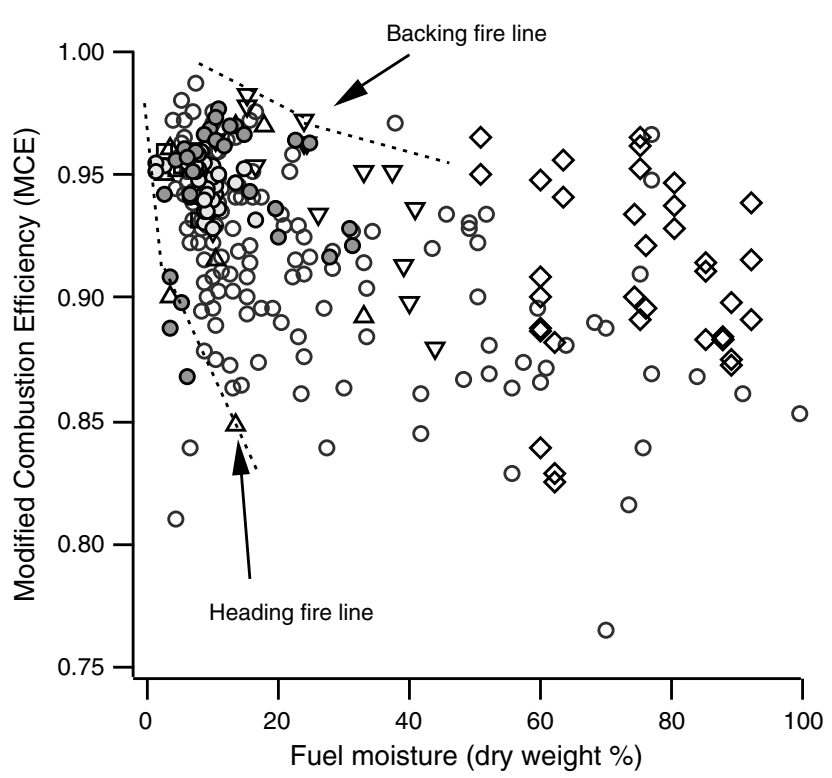

Figure 2. Fire-integrated MCE versus fuel moisture content from this study (solid light (SE) and dark (SW) gray circles), from Weise et al. [1991] for California chaparral (diamonds), from McMeeking et al. [2009] for a wide variety of U.S. domestic fuel types including Chaparral (cea, chs, and man; circles), and from Keene et al. [2006] for in-lab open burning of African savanna grassland: backing (downward triangle), mixed(square), and heading (upward triangle) fires. The dashed lines show the upper and lower limits of heading and backing fires.

[23] Fuel moisture (FM) may weakly affect the average burn MCE (Figure 2). Figure 2 was produced combining data from this study with selected other lab studies: Weise et al. [1991] for California chaparral, Keene et al. [2006] for African savanna, and McMeeking et al. [2009] for a wide variety of U.S. domestic fuels. The plot shows that all these studies have consistent MCE-FM results. The upper bound of MCE for FM $>20 \%$ stays relatively flat around 0.95 while the lower bound decreases with increasing FM. Upper and lower bounds both sharply converge to $\mathrm{MCE}=1$, when $\mathrm{FM}<20 \%$. The downward and upward triangles in Figure 2 indicate heading and backing fires, respectively [Keene et al., 2006]. As can be seen for FM up to $20 \%$, the average MCE appears to be bound by the fire propagation dynamics (backing/heading fire). Backing/heading fires represent two limiting combustion cases: A heading fire has larger flames, spreads faster, and leaves more unburned fuel behind while a backing fire has smaller flames, slower propagation rates, and higher combustion completeness [Ward, 1998; J. Peterson and B. Leenhouts, What wildland fire conditions minimize emissions and hazardous air pollutants and can land management goals still be met?, unpublished support document to the EPA Interim Air Quality Policy on Wildland and Prescribed Fires, 1997]. For example, Lobert et al. [1991] observed a $40 \%$ increase in the $\mathrm{CO} / \mathrm{CO}_{2}$ ratio going from a backing fire to a heading fire for laboratory savanna grass burns. The propagation factor (heading/backing fire) does not seem to be the dominant factor in MCE values for $\mathrm{FM}>30 \%$, since after this point the MCE is seemingly not bound by backing/heading fire data points.

\subsection{Total Particulate Emissions}

\subsubsection{Particle Matter Mass Emission Factors}

[24] The EFs in the current study are calculated based on the carbon mass-balance method [Ward et al., 1979; Burling et al., 2011]. Table 2 presents average particle emission factors for each fuel type studied. Particle number EFs as measured by the CPC and DMM are discussed in Text S1 of the supporting information. The average emission factors for $\mathrm{PM}_{2.5}\left(\mathrm{~g} \mathrm{PM}_{2.5}\right.$ per $\mathrm{kg}$ dry biomass burned $\left.\mathrm{EF}_{\mathrm{PM} 2.5}\right)$ measured in this study are plotted versus average MCE (Figure 3). Hereafter, we will use notation of (average one standard deviation) $\mathrm{g} \mathrm{kg}^{-1}<\mathrm{MCE}>$ for reporting emission factor and its corresponding MCE.

[25] The laboratory study of McMeeking et al. [2009] reported an average $\mathrm{EF}_{\mathrm{PM} 2.5}$ for chaparral fuels of $11.6 \pm 15.1 \mathrm{~g} \mathrm{~kg}^{-1}<0.909 \pm 0.029>$ that includes $7.8 \pm 1.2$ $\mathrm{g} \mathrm{kg}^{-1}<0.913 \pm 0.012>, 6.5 \pm 4.2 \mathrm{~g} \mathrm{~kg}^{-1}<0.914 \pm 0.030>$, and $23.5 \pm 25.9 \mathrm{~g} \mathrm{~kg}^{-1}<0.899 \pm 0.030>$ for cea, chs, and man, respectively. The current study has lower PM emissions for chs and man, mainly attributed to the higher MCEs (for these specific fuels) in this study. However, cea is higher in the current study, likely due to lower combustion temperatures from the poorly combusted fuel bed. The $\mathrm{EF}_{\mathrm{PM} 2.5}$ response to MCE in our study (slope $=248.8$, Figure 3) is $80 \%$ of that reported by McMeeking et al. [2009] (slope $=311.1$ for $\mathrm{EF}_{\mathrm{PM} 2.5}[$ McMeeking et al., 2009, Figure 9]).

[26] Size-resolved PM mass speciation using a microorifice uniform deposit impactor (MOUDI) was obtained for six burns (see Figure S2 in the supporting information). The size distribution of PM peaked in the particle accumulation mode with an aerodynamic diameter that ranged (depending on fuel type shown in parentheses) between the eighth stage $(2 \mathrm{yr} / \mathrm{CL}$ and $1 \mathrm{yr} / \mathrm{CL} ; 0.18 \mu \mathrm{m}$ cut-size; CL: Camp Lejeune) and tenth stage (oas, cea, cuh, and mes; $0.056 \mu \mathrm{m}$ cut-size). The PM mass in the size range 3.2$18 \mu \mathrm{m}$ varied between 2 and $18 \%$ of the $\mathrm{PM}_{3.2}$ mass with an average of $10 \% \pm 6 \%$. The ratio of $\mathrm{EF}_{\mathrm{PM} 10}$ to $\mathrm{EF}_{\mathrm{PM} 3.2}$ was 1.00-1.07; this is consistent with the $\mathrm{PM}_{10}$ to $\mathrm{PM}_{2.5}$

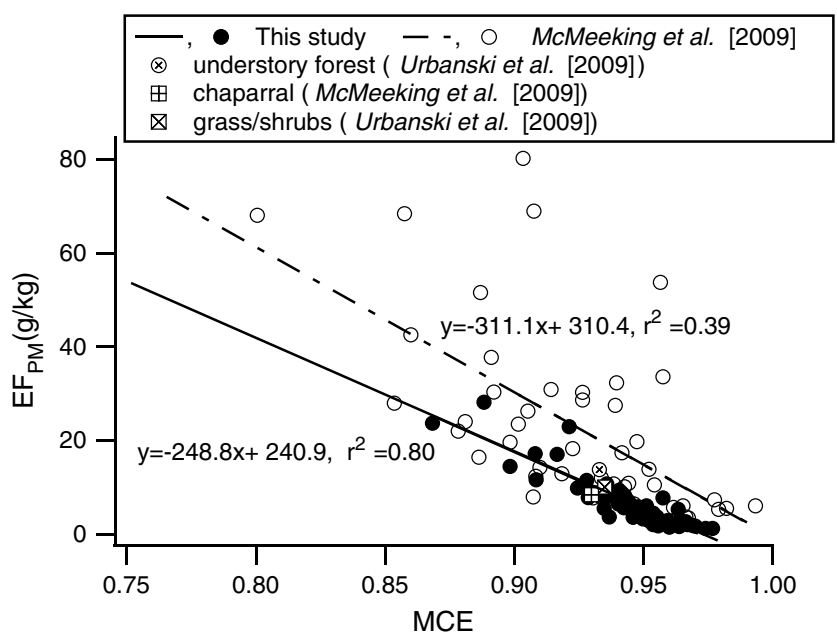

Figure 3. Particulate matter $\left(\mathrm{PM}_{2.5}\right)$ as a function of modified combustion efficiency (MCE). Black solid circles are EF for $\mathrm{PM}_{2.5}$ measured for this study. Solid and dashed lines represent the linear regression of $\mathrm{PM}_{2.5}$ onto MCE for the current and McMeeking et al. [2009] study. 


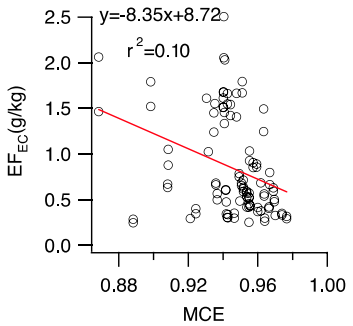

(a)

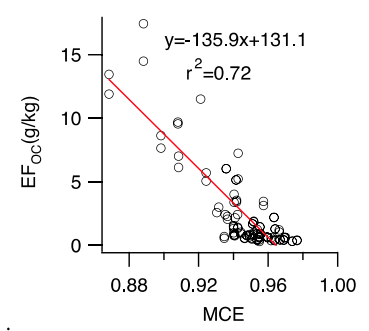

(b)

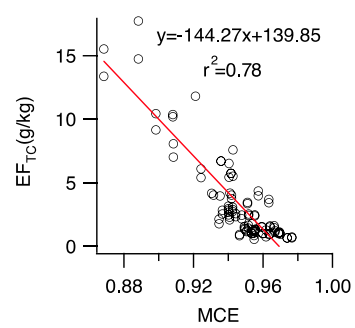

(c)

Figure 4. Fire-integrated $\mathrm{PM}_{2.5}$ emission factors plotted versus MCE for (a) elemental carbon (EC), (b) organic carbon (OC), and (c) total carbon (TC).

mass ratio of 1.09 of McMeeking et al. [2009]. For quality control purposes, we correlated the total accumulated mass on the MOUDI stages against the Teflon filter mass on the same fire. The total accumulated MOUDI mass was $27 \%$ higher than the Teflon filters mass (the correlation is shown in Figure S2g, $\left.r^{2}=0.99\right)$. According to Reid et al. [2005], coarse-mode particles can contribute to $10-20 \%$ of the total collected PM mass consistent with the current study.

\subsection{Particle Component Emission Factors}

\subsubsection{Organic and Elemental Carbon}

[27] Integrated $\mathrm{EF}_{\mathrm{OC}}, \mathrm{g}$ carbon/kg fuel burned, for all the burns is plotted as a function of MCE (Figure $4 \mathrm{~b}$ ). $\mathrm{EF}_{\mathrm{OC}}$ is observed to negatively correlate with $\operatorname{MCE}\left(r^{2}=0.72\right)$. The lit/FB (FB: Fort Benning) from SE fuels emitted the highest amount of OC per $\mathrm{kg}$ fuel burned $\left(10.60 \pm 3.64 \mathrm{~g} \mathrm{~kg}^{-1}\right.$ $<0.894 \pm 0.017>$ ), and oas/FHUA (FHUA: Fort Huachuca) from SW the lowest $\left(0.44 \pm 0.10 \mathrm{~g} \mathrm{~kg}^{-1}<0.971\right.$ $\pm 0.004>$ ). Comparisons of literature $\mathrm{EF}_{\mathrm{OC}}$ must account for MCE since OC emission factors are highly dependent on MCE. McMeeking et al. [2009] reports $\mathrm{EF}_{\mathrm{OC}}$ of 1.8 $<0.913>, 1.5<0.914>$, and $7.1<0.899>\mathrm{g} / \mathrm{kg}$ dry fuel for chaparrals cea, chs, and man, respectively, similar to Table 2 values but slightly overestimated by the proposed $\mathrm{EF}_{\mathrm{OC}}$ versus $\mathrm{MCE}$ line (Figure 4b). Andreae and Merlet [2001] suggest $\mathrm{EF}_{\mathrm{OC}}$ of $3.4 \mathrm{~g} \mathrm{~kg}^{-1}<0.94>$ for savanna and grassland that agrees well with the given $\mathrm{EF}_{\mathrm{OC}}-\mathrm{MCE}$ linear fit. Overall, SE fuels generally led to higher $\mathrm{EF}_{\mathrm{OC}}$ compared to $\mathrm{SW}$ fuels at similar MCEs. The only exception is cuh/CL of SE, which was similar to SW fuels.

[28] Integrated $\mathrm{EF}_{\mathrm{EC}}$ as a function of $\mathrm{MCE}$ is plotted in Figure $4 \mathrm{a}$. The $\mathrm{EF}_{\mathrm{EC}}(\mathrm{g} / \mathrm{kg})$ ranged from $0.47 \mathrm{~g} \mathrm{~kg}^{-1}$ $<0.965>$ to $1.54 \mathrm{~g} \mathrm{~kg}^{-1}<0.944>$ for SW fuels and from $0.41 \mathrm{~g} \mathrm{~kg}^{-1}<0.954>$ to $1.51 \mathrm{~g} \mathrm{~kg}^{-1}<0.945>$ for SE fuels, respectively. The highest $\mathrm{EF}_{\mathrm{OC}}$ in $\mathrm{SE}$ and $\mathrm{SW}$ group is from cas/FHL (FHL: Fort Hunter Liggett) and uh/CL, respectively; the lowest $\mathrm{EF}_{\mathrm{EC}}$ values for $\mathrm{SE}$ and $\mathrm{SW}$ were cuh/CL and oaw/FHUA. No $\mathrm{EF}_{\mathrm{EC}}$ ecosystem dependency was observed. Further, Andreae and Merlet [2001] suggest an $\mathrm{EF}_{\mathrm{EC}}$ of $\sim 0.48 \mathrm{~g} \mathrm{~kg}^{-1}<\sim 0.94>$ for savanna and grassland fuels that is comparable with the average of chaparral fuels in this study $1.08 \mathrm{~g} \mathrm{~kg}^{-1}<0.945>$. The correlation between $\mathrm{EF}_{\mathrm{EC}}$ and MCE is much weaker $\left(r^{2}=0.10\right)$ than the correlation between $\mathrm{EF}_{\mathrm{OC}}$ and MCE.

[29] Intense flaming significantly increases the fraction of elemental carbon (EC) emissions in the total PM carbon emissions (TC). Figure 5 illustrates the relationship between the $\mathrm{EC} / \mathrm{TC}$ ratio and average $\mathrm{MCE}$. EC/TC was lower than
0.15 for MCEs smaller than 0.93, while this value strongly rose to 0.7 for MCEs larger than 0.95 . The results are consistent with previous studies (e.g., as shown in the figure for McMeeking et al. [2009] and Christian et al. [2003]). Reid et al. [2005] suggest values between 0.05 and 0.18 for flaming, and 0.03 and 0.075 for smoldering. However, Reid et al. define smoldering as $\mathrm{MCE}<0.9$; furthermore, their EC/TC numbers mostly originate from field studies, which rarely achieve $\mathrm{MCE}>0.95$ compared to up to 0.98 achieved in the lab where EC/TC rises quickly. Even accounting for $\mathrm{MCE}$, field EC/TC values are lower than lab EC/TC. For example, the airborne study of Sinha et al. [2004] sampled fires from African savannah grasses. They measured EC/TC ratios of $0.135<0.959>$ and $0.255<0.976>$ for miombo woodland and dambo grassland fires, respectively. During the flaming phase in our experiment, we observed temperatures up to $\sim 70^{\circ} \mathrm{C}$ at the instrumentation platform level with measured filter surface temperatures of $27-30^{\circ} \mathrm{C}$; it is possible that the NMOC requires more time to condense to the particle phase, as indicated by the lower EC/TC ratios of airborne studies.

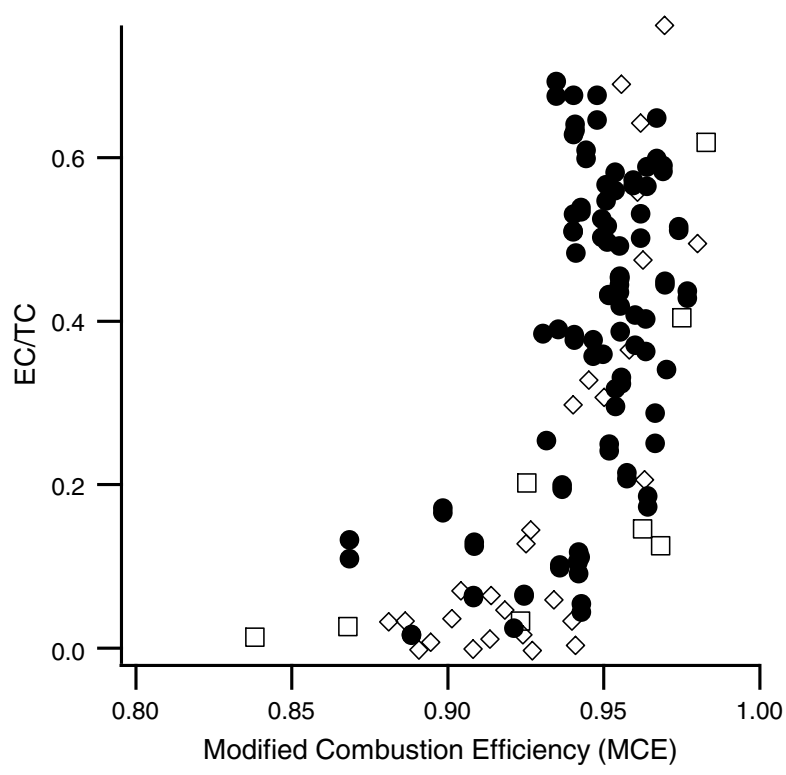

Figure 5. Particle elemental carbon to total carbon ratio (EC/TC) plotted versus modified combustion efficiency (MCE). Solid circles represent EC/TC measured in this study. Also shown are open diamonds [McMeeking et al., 2009] and open squares [Christian et al., 2003]. 


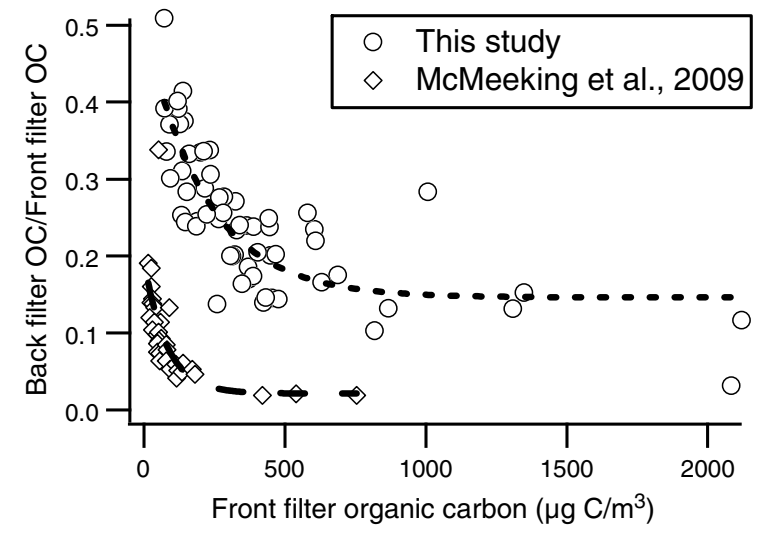

Figure 6. Mass fraction of semi-volatile organic compounds in total collected organic carbon (OC); open circles are data from this study (best exponential fit: $0.146+0.355 \mathrm{e}^{-0.004 x}$, $r^{2}=0.68$ ) and open diamonds from McMeeking et al. [2009] (best exponential fit: $0.021+0.173 \mathrm{e}^{-0.012 x}, r^{2}=0.77$ ).

[30] EC/TC ratio increases rapidly as MCE increases past 0.94 (Figure 5). The same fact can be seen in Figures 9a and 9b of McMeeking et al. [2009]. Reid et al. [2005] also noted through investigation of previous studies on fires from savanna/grass/cerrado, tropical forest, etc., for phases of flaming/smoldering set forth that the black carbon content of PM during flaming can be a factor of 5 higher than during smoldering.

[31] Compared to McMeeking et al. [2009], the current study has nearly seven times higher adsorption artifacts for $\mathrm{OC}>500 \mu \mathrm{g} / \mathrm{m}^{3}$ and almost twice higher for $0-100 \mu \mathrm{g} / \mathrm{m}^{3}$ (Figure 6), and the data are more scattered as well. The mass fraction of artifact exponentially $\left(0.146+0.355 \mathrm{e}^{-0.004 x}\right.$ and $0.021+0.173 \mathrm{e}^{-0.012 x}$ ) decreased with increase in concentration of smoke for the current and McMeeking et al. studies, respectively. McMeeking et al. [2009] used significantly less amount of fuel for each burn and this might have led to cooler diluted smoke, enhanced partitioning of gas into particle phase, and subsequently less artifacts, while in the current study the weight of the fuel bed varied between 250 and $5500 \mathrm{~g}$, averaging $2470 \pm 1090 \mathrm{~g}$. Moreover, it has been shown that due to lower Teflon adsorption artifact, quartz filter behind Teflon filter reports higher adsorption artifact than quartz filter behind quartz filter [Chow et al., 2006]. OC measurement in the current study was not field blank subtracted.

\subsection{Particle Inorganic Content}

\subsubsection{Particle Inorganic Content Metals:} X-ray Fluorescence (XRF) Analysis

[32] Teflon filters collected on 50 different burns were analyzed for $\mathrm{Cl}, \mathrm{Br}, \mathrm{Si}, \mathrm{P}, \mathrm{S}$, and metals (atomic mass number $\mathrm{Na}-\mathrm{Pb}$ ). The dominant elements, by mass fraction, in order of decreasing median ranking by burn were $\mathrm{K}, \mathrm{Cl}, \mathrm{Na}, \mathrm{S}$, $\mathrm{Zn}, \mathrm{Mg}, \mathrm{Si}$, and $\mathrm{Ca}$ with potassium the dominant element in 47 of the 50 filters analyzed. In the vast majority of burns with XRF data (28 of 50), the elements $\mathrm{K}, \mathrm{Cl}, \mathrm{Na}$, and $\mathrm{S}$ comprised $>90 \%$ of the inorganic elemental mass. As discussed in Akagi et al. [2011], the properties of particles emitted by biomass burning can change rapidly after emission. The cooling/dilution regime experienced by emissions in the laboratory may be very different from that realized by emissions of a "real fire" burning in the natural environment. It is possible that the contribution of semi-volatile organic compounds to organic particle formation and growth is not as efficient in the lab environment. However, the amount of elemental carbon and metals cannot change after emission. Therefore, the EF values of inorganic elements measured in our laboratory burns are applicable to fires in the natural environment; however, the mass percentages are likely overestimated due to incomplete condensation of gas-phase semi-volatile organic compound.

[33] The mass of all inorganic elements as a percent of total $\mathrm{PM}_{2.5}$ mass ranged from 1 to $56 \%$ and varied strongly with fuel type and source location. The mass percent for $\mathrm{K}, \mathrm{Cl}$, $\mathrm{Na}$, and $\mathrm{S}$ is shown in Figure 7. Fuels harvested from SW consistently produced particles with higher $\mathrm{K}$ and $\mathrm{Cl}$ mass fractions than the fuels from SE. By source location, the average $\mathrm{K}$ and $\mathrm{Cl}$ mass percent for $\mathrm{SW}$ fuels was Vandenberg Air Force Base (VAFB): $\mathrm{K}=17.1( \pm 4.0) \%, \quad \mathrm{Cl}=16.4$ $( \pm 5.3) \%$; FHL: $\mathrm{K}=10.5( \pm 5.1) \%, \mathrm{Cl}=4.9( \pm 3.4) \%$; and FHUA: $\mathrm{K}=13.7( \pm 3.0) \%, \mathrm{Cl}=6.9( \pm 1.3) \%$. The particulate mass fractions of these elements are higher than in previous reports, which may be due to incomplete condensation of gas-phase non-methane organic compound (NMOC) as the plume cools. However, Chang-Graham et al. [2011] noted unusual metallo-organic species noted detected previously in biomass burning aerosol and hypothesized that land use practice on the military bases where the fuels were collected could contribute. Further, the ratios between metals and metals and EC should not be affected by any possible temperature artifacts.

[34] The PM mass fractions of $\mathrm{Cl}, \mathrm{K}$ (and also $\mathrm{Na}$ for VAFB), and the sum of all inorganics produced by the southwestern fuels are on the upper end of values found in the literature. The studies reviewed by Reid et al. [2005], which covered a wide range of biomass (South American grassland, African savanna, Cerrado, and North American temperate forest and tropical broadleaf forest), reported that inorganic trace species emissions were highly variable and accounted for $\sim 5-15 \%$ of PM mass. Of 10 studies reviewed by Reid et al. [2005], the percent of PM mass consisting of $\mathrm{K}$ ranged from 0.4 to $18 \%$ and the $\mathrm{Cl}$ mass percent ranged from 0.2 to $11 \%$. Andreae and Merlet [2001] recommend particulate $\mathrm{K}$ emission factors that correspond to $6 \%, 3 \%$, and $1-3 \%$ of their recommended $\mathrm{EF}_{\mathrm{PM} 2.5}$ for savanna/grassland, tropical forest, and extratropical forest biomass, respectively. In the laboratory study of McMeeking et al. [2009], results for a large variety of fuels, classified according to five broad vegetation groups (montane, rangeland, chaparral, southeast U.S. coastal plain, and boreal) produced average mass percent of $\mathrm{K}$ and $\mathrm{Cl}$ that each ranged from $\sim 0.3$ to $6 \%$. At the less generalized classification of fuel type, the results of McMeeking et al. [2009] differ widely, with the mass percentages of $\mathrm{K}$ and $\mathrm{Cl}$ varying between 0.1 and $19.4 \%$ and between 0.1 and $18.4 \%$, respectively.

[35] Emission factors for $\mathrm{K}, \mathrm{Cl}, \mathrm{Na}$, and $\mathrm{S}$ in $\mathrm{PM}_{2.5}$ are provided in Table 2 . EF for $\mathrm{K}, \mathrm{Cl}$, and $\mathrm{Na}$ varied significantly by fuel. Fuels from VAFB and FHL had the largest $\mathrm{EF}_{\mathrm{K}}, \mathrm{EF}_{\mathrm{Cl}}$, and $\mathrm{EF}_{\mathrm{Na}}$ (with VAFB being significantly larger than FHL), while the fuels from the southeast had the smallest. $\mathrm{EF}_{\mathrm{K}}$, $\mathrm{EF}_{\mathrm{Cl}}$, and $\mathrm{EF}_{\mathrm{Na}}$ were highest for the fuels from VAFB and 


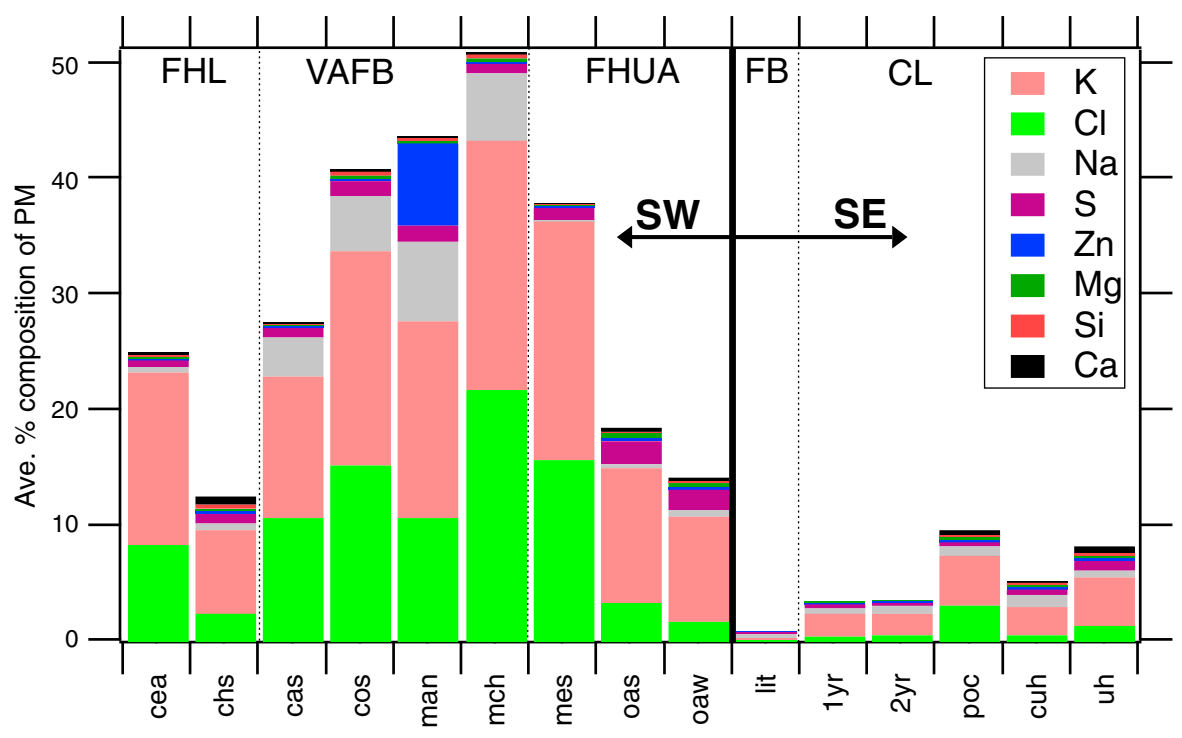

Figure 7. Percentage composition of PM mass comprised by the elements $\mathrm{K}, \mathrm{Cl}, \mathrm{Na}, \mathrm{S}, \mathrm{Zn}, \mathrm{Mg}$, Si, Ca for 41 burns, segregated by fuel type and site origin.

FHL and lowest for the southeast fuels. The oas and oaw fuels from FHUA had $\mathrm{EF}_{\mathrm{K}}, \mathrm{EF}_{\mathrm{Cl}}$, and $\mathrm{EF}_{\mathrm{Na}}$ similar to the southeast fuels, while $\mathrm{EF}_{\mathrm{K}}$ and $\mathrm{EF}_{\mathrm{Cl}}$ for mes were comparable to that measured for the Pacific coast fuels (VAFB and FHL). The differences can be explained largely by the chemical composition of the vegetation making up the fuels. The VAFB and FHL fuels had representative $\mathrm{Cl}, \mathrm{K}$, and $\mathrm{Na}$ (Table 1). In contrast, the SE fuels and FHUA oas and oaw had concentrations of these elements that were very low (Table 1). The chemistry of the mes from FHUA was an outlier, high in $\mathrm{Cl}$ and $\mathrm{K}$, but low in $\mathrm{Na}$. The high $\mathrm{Cl}$ and $\mathrm{K}$ for the mes fuel were largely due to the desert broom component, a shrub species that has been identified as a possible element hyper-accumulator.

[36] We may compare our chaparral metal/halogen results with McMeeking et al. [2009], who report chaparral emissions for $\mathrm{K}, \mathrm{Cl}, \mathrm{Na}$, and $\mathrm{S}$. Our chaparral average $\mathrm{EF}_{\mathrm{K}}$ of $0.652 \mathrm{~g} \mathrm{~kg}^{-1}$ is similar to McMeeking et al. [2009] $\left(\mathrm{EF}_{\mathrm{K}}=0.50 \mathrm{~g} \mathrm{~kg}^{-1}\right)$, while our $\mathrm{EF}_{\mathrm{Cl}}$ is over twice as large $\left(0.471 \mathrm{~g} \mathrm{~kg}^{-1}\right.$ versus $\left.0.20 \mathrm{~g} \mathrm{~kg}^{-1}\right)$ and our $\mathrm{EF}_{\mathrm{Na}}$ differs greatly $\left(0.143 \mathrm{~g} \mathrm{~kg}^{-1}\right.$ versus below detection limit). Considering the strong link we observed between the element content of the fuels and their respective particle EF, it is likely the differences in EF are due to fuel chemistry. McMeeking et al. [2009] do not report fuel chemistry; however, it is possible the $\mathrm{Cl}$ and $\mathrm{Na}$ content of the fuel samples burned in their study was significantly less than that in our study. Among the southwestern fuels, those with an "oak" wood component (chs of California, oas and oaw of Arizona) produced particles with $\mathrm{K}(9.4 \pm 3.2 \%)$ and $\mathrm{Cl}$ $(2.4 \pm 1.1 \%)$ mass fractions that were significantly lower than those of the other six fuels types studied from this region (average $18.0 \pm 4.4 \%$ and $11.9 \pm 5.5 \%$ ) - see Figure 7 . Interfuel differences for both elements are significant at the $p<0.001$ level. These observations, along with the lack of a significant correlation with $\mathrm{MCE}$, indicate that location and vegetation composition both influence the chemical composition of fuels. We believe both factors are responsible for the difference in $\mathrm{EF}_{\mathrm{Cl}}$ and $\mathrm{EF}_{\mathrm{Na}}$ observed between our study and McMeeking et al. [2009]. The Cl content in vegetation and chloride deposition has been observed to show a strong gradient with distance from the Pacific coast [McKenzie et al., 1996]. Since our chaparral fuels were sampled at coastal sites, while McMeeking et al. [2009] studied chaparral harvested $150 \mathrm{~km}$ east of Los Angeles, the fuels used in the latter would be expected to have a lower content of $\mathrm{Cl}, \mathrm{Na}$, and other sea-salt elements.

[37] The percentage of particulate mass as $\mathrm{K}$ or $\mathrm{S}$ was weakly correlated with average $\mathrm{MCE}\left(r^{2}=0.20\right.$ for $\mathrm{K}$ and $r^{2}=0.40$ for $\mathrm{S}$ ), while the $\mathrm{Cl}$ and $\mathrm{Na}$ mass fractions had no correlation. The lack of a significant correlation between inorganic particulate emissions and average MCE is consistent with the findings of McMeeking et al. [2009] and Christian et al. [2003], although Ward and Hardy [1991] found $\mathrm{EF}_{\mathrm{K}}$ (flaming) was roughly 10 times higher than $\mathrm{EF}_{\mathrm{K}}$ (smoldering). The Ward and Hardy [1991] study was all from fires of the same fuel type, whereas this and the other studies cited were across many different fuel types. It is possible that the fuel variations may mask any $\mathrm{MCE}$ dependence for these studies.

[38] The particulate emissions of $\mathrm{Cl}$ and gas-phase $\mathrm{HCl}$ $\left(\mathrm{EF}_{\mathrm{HCl}}\right)$ as measured by OP-FTIR were not correlated with average MCE and we suspect their variability is driven by fuel composition. Any underlying dependence of $\mathrm{PM} \mathrm{Cl}$ and $\mathrm{HCl}$ emissions on combustion behavior, in particular, the partitioning of evolved fuel $\mathrm{Cl}$ between the gas and particulate phase, if present, may be masked by wide variations in fuel $\mathrm{Cl}$ content. The EFs of particulate $\mathrm{Cl}$ to $\mathrm{HCl}$ as a function of MCE were investigated to account for the variability of the fuel $\mathrm{Cl}$ content. No significant correlation between the ratio $\mathrm{EF}_{\mathrm{PM}(\mathrm{Cl})} / \mathrm{EF}_{\mathrm{PM}(\mathrm{HCl})}$ and $\mathrm{MCE}$ (plot not shown) was observed, a result that indicates combustion behavior (as represented by $\mathrm{MCE}$ ) is not an important factor in $\mathrm{Cl}$ partitioning between these two species.

\subsubsection{Ionic Inorganic species}

[39] Inorganic ion species emission factors are provided in Table 3. Similar to the emission factor of crustal elements, potassium and chloride were the most abundant ions and 
HOSSEINI ET AL.: PARTICLE EMISSIONS FROM BIOMASS BURNING

Table 3. Aerosol-Phase Emission Factors of Cations and Anions (mg/kg Fuel Burned) ${ }^{\mathrm{a}}$

\begin{tabular}{|c|c|c|c|c|c|c|c|c|}
\hline Species/Group & Sulfate & Nitrite & Chloride & Bromide & Sodium & Ammonium & Potassium & Calcium \\
\hline \multicolumn{9}{|c|}{ Southwest } \\
\hline cea/FHL & $-{ }^{b}$ & - & $481 \pm 175$ & - & $713 \pm 953$ & - & $392 \pm 94$ & 103 \\
\hline chs/FHL & $141 \pm 51$ & - & $178 \pm 36$ & - & $243 \pm 229$ & - & $365 \pm 160$ & - \\
\hline cas/VAFB & $208 \pm 59$ & - & $1410 \pm 460$ & - & $458 \pm 178$ & 130 & $1190 \pm 340$ & - \\
\hline $\cos /$ VAFB & $248 \pm 28$ & 60.0 & $1070 \pm 120$ & - & $332 \pm 44$ & - & $1280 \pm 200$ & - \\
\hline $\operatorname{man} / \mathrm{VAFB}$ & $102 \pm 18$ & 27.3 & $301 \pm 98$ & 8.11 & $143 \pm 59$ & - & $409 \pm 101$ & - \\
\hline $\mathrm{mch} / \mathrm{VAFB}$ & $92 \pm 25$ & - & $874 \pm 103$ & - & $213 \pm 47$ & 91.4 & $823 \pm 86$ & - \\
\hline Chaparral ave. & $158 \pm 46$ & $43.7 \pm 23.1$ & $719 \pm 341$ & 8.11 & $350 \pm 707$ & $110 \pm 38$ & $743 \pm 254$ & 103 \\
\hline mes/FHUA & $118 \pm 16$ & - & $590 \pm 125$ & - & $187 \pm 80$ & $167 \pm 7$ & $622 \pm 146$ & - \\
\hline oas/FHUA & $78.9 \pm 10.1$ & - & $61.4 \pm 4.2$ & - & $95.6 \pm 17.1$ & - & $119 \pm 28$ & - \\
\hline oaw/FHUA & $85.2 \pm 6.1$ & - & $43.4 \pm 10.8$ & - & $64.6 \pm 13.6$ & - & $143 \pm 72$ & - \\
\hline FHUA ave. & $94.0 \pm 12.1$ & - & $231 \pm 86$ & - & $116 \pm 56$ & $167 \pm 7$ & $295 \pm 105$ & - \\
\hline \multicolumn{9}{|c|}{ Southeast } \\
\hline lit/FB & - & - & $125 \pm 40$ & - & $379 \pm 150$ & - & - & - \\
\hline $1 \mathrm{yr} / \mathrm{CL}$ & - & - & $125 \pm 15$ & - & $402 \pm 77$ & - & - & - \\
\hline $2 \mathrm{yr} / \mathrm{CL}$ & - & - & $175 \pm 60$ & - & $357 \pm 64$ & - & - & - \\
\hline $\mathrm{poc} / \mathrm{CL}$ & - & - & $114 \pm 12$ & - & $117 \pm 63$ & - & $101 \pm 51$ & - \\
\hline $\mathrm{cuh} / \mathrm{CL}$ & - & - & $33.8 \pm 11.1$ & - & 97.5 & - & - & - \\
\hline $\mathrm{uh} / \mathrm{CL}$ & $142 \pm 10$ & 231 & $16 \pm 39$ & - & $195 \pm 7$ & - & $246 \pm 148$ & 189 \\
\hline Camp Lejeune ave. & $142 \pm 10$ & - & $92.8 \pm 44.5$ & - & $233 \pm 64$ & - & $173 \pm 110$ & 189 \\
\hline
\end{tabular}

${ }^{\mathrm{a}}$ The values represent mean \pm one standard deviation across repeated experiments.

byphen (-) indicates "below detection limit".

were strongly correlated with each other $($ slope $=1.03$; $r^{2}=0.89$ ). Fuels from $\mathrm{SW}$, compared to the fuels from $\mathrm{SE}$, emitted much higher amounts of $\mathrm{Cl}^{-}, \mathrm{K}^{+}, \mathrm{SO}_{4}{ }^{2-}$, and $\mathrm{Na}^{+}$ per unit mass of fuel burned. This is consistent with our results from the previous section. The mass concentrations of nitrite, nitrate, and ammonium for most of filters were below detection limit. These species form rapidly post emission as reported elsewhere [Yokelson et al., 2009; Akagi et al., 2012].

[40] Chlorine was the most abundant inorganic species in the $\mathrm{PM}_{2.5}$ aerosol, accounting for $0.4-24.5 \%$ of the soluble inorganic mass concentration. McMeeking et al. [2009] found that chlorine accounted for $2-9 \%$ of $\mathrm{PM}_{2.5}$ mass for several of the same fuels burned in this study including chaparral and sagebrush. Similar to our study, they observed high $\mathrm{Cl}^{-}$mass fraction ( $60 \%$ of inorganics). $\mathrm{EF}_{\mathrm{Cl}^{-}}$varied from 0 to $1.23 \mathrm{~g} / \mathrm{kg}$ of fuel burned depending on the fuel type and source location. The study average was $0.34 \pm 0.35 \mathrm{~g} / \mathrm{kg}$. The $\mathrm{EF}_{\mathrm{Cl}^{-}}$values reported were $1-2 \mathrm{~g} / \mathrm{kg}, 0-1.8 \mathrm{~g} / \mathrm{kg}$, $0-1.8 \mathrm{~g} / \mathrm{kg}$, and $0-3.2 \mathrm{~g} / \mathrm{kg}$ from Andreae and Merlet [2001], Christian et al. [2003], Keene et al. [2006], and McMeeking et al. [2009], respectively.

[41] Sulfate emission factors ranged from 0 to $0.22 \mathrm{~g}$ $\mathrm{SO}_{4}{ }^{2-} / \mathrm{kg}$ fuel and were weakly correlated with average $\operatorname{MCE}\left(r^{2}=0.48\right)$. Also comparing XRF to IC results, it can be inferred that $\sim 89 \%$ of the particulate sulfur element is in the form of $\mathrm{SO}_{4}{ }^{2-}$. Sinha et al. [2003] estimated an average $0.16 \mathrm{~g}$ sulfate per $\mathrm{kg}$ of fuel burned for savanna fires, while Andreae and Merlet [2001] recommended $0.37 \mathrm{~g} / \mathrm{kg}$. $\mathrm{EF}_{\mathrm{SO}_{4}^{2-}}$ is affected by the age of smoke and the nutrient content of the fuel [Yokelson et al., 2009]. As a smoke plume ages, the $\mathrm{SO}_{2}(\mathrm{~g})$ oxidizes in aqueous phase to $\mathrm{H}_{2} \mathrm{SO}_{4}$ and then partners with positive ions such as potassium and ammonium in the particles, thereby increasing aerosol $\mathrm{SO}_{4}$ mass fraction over time. In the airborne studies of northern tropics deforestation, Yokelson et al. [2009] showed that sulfate mass concentration can increase 3 times during a time interval of $\sim 1 \mathrm{~h}$. In their study, sulfate made up to $1.5 \%$ of $\mathrm{PM}_{1}$ mass from nascent smoke, while in our study it made up to
$7.5 \%$ of $\mathrm{PM}_{2.5}$ mass for very fresh smoke. The sulfate content differences are attributed to the different sulfur content of the fuel. In our study, sulfate was also weakly correlated with average $\operatorname{MCE}\left(r^{2}=0.48\right)$.

[42] Non-soil, non-sea-salt potassium (often denoted "nsnss-K") is an important tracer of biomass burning aerosol [Andreae and Merlet, 2001]. Potassium was the second most abundant ionic species in this study varying between 0.03 and $1.40 \mathrm{~g} / \mathrm{kg}$ fuel burned. The emission factor of potassium from XRF was $12 \%$ higher than the ionic $\mathrm{K}$ from ion chromatography (IC) $\left(r^{2}=0.83\right)$ indicating the vast majority of potassium is in ionic form. Our results are consistent with the laboratory studies of McMeeking et al. [2009] and Christian et al. [2003] that reported an emission factor of 0.03 to $1.50 \mathrm{~g} / \mathrm{kg}$ for a variety of U.S. domestic fuels and 0.02 to $1.29 \mathrm{~g} / \mathrm{kg}$ for African, Indonesian fuels. However, we report $\mathrm{EF}_{\mathrm{K}^{+}}$that is twice the $\mathrm{EF}_{\mathrm{K}^{+}}$that McMeeking et al. [2009] obtained for chaparral.

[43] Among all the southeastern and southwestern fuels, fuels from VAFB had the highest mass percent of ionic inorganic species ranging from $\sim 9$ to $62 \%$, while emissions from Camp Lejeune fuels had the lowest amount of inorganic PM $(\sim 2-15 \%)$. Other than fuel source location, fuel type also affected the ionic species emissions. For example, among the fuel from VAFB, fuel code "man" has the least amount of $\mathrm{Cl}^{-}(301.0 \pm 97.7 \mathrm{mg} / \mathrm{kg}$ fuel burned), while fuel code "cas" from the same location has the greatest amount (1406 $\pm 457 \mathrm{mg} / \mathrm{kg}$ fuel burned). These observations coupled with the lack of significant correlation with MCE suggest that fuel composition and vegetation type play the dominant role in emissions of ionic species. Very little to lower than detection limit amounts of calcium, ammonium, bromide, and nitrite were found. These species comprise the remainder of the inorganic ions. No dependency on average MCE was observed for any of these ions. A slight correlation between $\mathrm{Na}^{+}$ and average $\operatorname{MCE}\left(r^{2}=0.19\right)$ without any regional dependency was observed. 


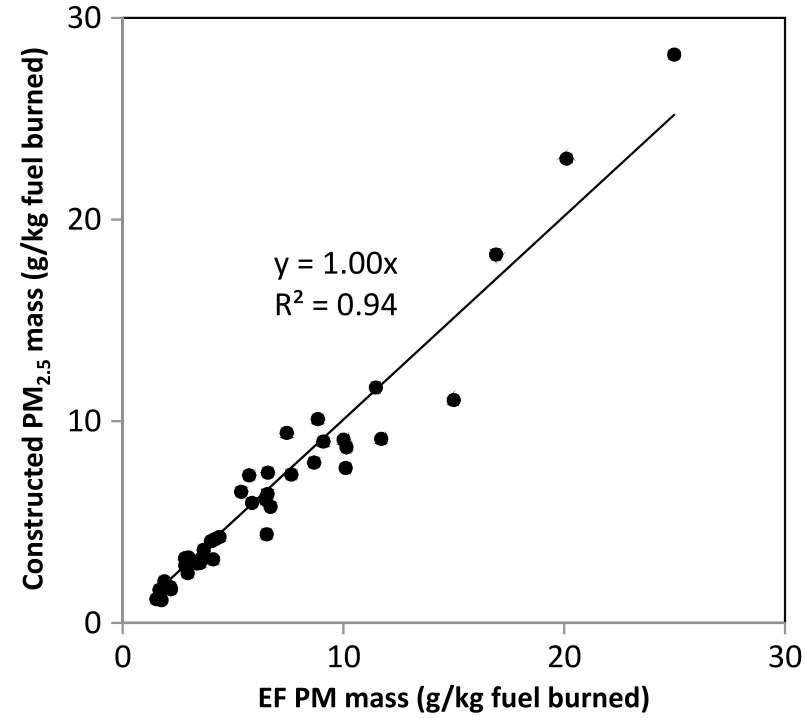

Figure 8. Reconstructed $\mathrm{PM}_{2.5}$ mass emission factor $(\mathrm{g} / \mathrm{kg}$ fuel burned) versus gravimetric $\mathrm{PM}_{2.5}$ mass emission factor. Solid line represents the regression line with slope of 1 and correlation coefficient of 0.94 .

\section{Elemental Analysis of the PM Filters}

\subsection{Mass Balance}

[44] The $\mathrm{PM}_{2.5}$ mass was reconstructed based on OC, EC, metals, and water-soluble ions from ion chromatography (IC) analysis. The relation that is considered here is as follows:

$$
\mathrm{EF}_{\mathrm{PM} 2.5}=\mathrm{EF}_{\mathrm{EC}}+\mathrm{EF}_{\mathrm{OM}}+\sum \mathrm{EF}_{\mathrm{XRF}}+\sum \mathrm{EF}_{\mathrm{IC}}
$$

where the terms on the right-hand side are the sum of the emission factors of elemental carbon $\left(\mathrm{EF}_{\mathrm{EC}}\right)$, organic mass $\left(\mathrm{EF}_{\mathrm{OM}}=\right.$ factor $\left.\times \mathrm{EF}_{\mathrm{OC}}\right)$, elemental crustal material $\left(\sum \mathrm{EF}_{\mathrm{XRF}}\right)$, and inorganic salts $\left(\sum \mathrm{EF}_{\mathrm{IC}}\right)$ for the $i$ th burn.

[45] Mass reconstruction followed Levin et al. [2010]; $\mathrm{Cl}^{-}$ was paired to $\mathrm{K}^{+}$as $\mathrm{KCl}$, excess $\mathrm{K}^{+}$was then balanced with
$\mathrm{K}_{2} \mathrm{SO}_{4}$ and $\mathrm{KNO}_{3}$, whereas excess $\mathrm{Cl}^{-}$was balanced with $\mathrm{NH}_{4} \mathrm{Cl}$ and $\mathrm{NaCl}$. Any remaining ions were explicitly accounted for in the salt group. Following the IMPROVE protocol [Pitchford et al., 2007], an assumption was made to consider all $\mathrm{Ca}$ and $\mathrm{Al}$ from $\mathrm{XRF}$ analysis as $\mathrm{CaO}$ and $\mathrm{Al}_{2} \mathrm{O}_{3}$.

[46] The EF of organic matter $\left(\mathrm{EF}_{\mathrm{OM}}\right)$ was estimated by multiplying the organic carbon emission factor by a factor of 1.52 to account for associated $\mathrm{O}, \mathrm{H}$, and $\mathrm{N}$. This $\mathrm{OM} / \mathrm{OC}$ value minimizes the difference between the actual and the constructed PM masses, is within the range recommended by Reid et al. [2005], and is consistent with the $\mathrm{OM} / \mathrm{OC}$ ratio acquired by the AMS in this study [Qi et al., 2012]. Additionally, the value is similar to the factors of 1.5 and 1.55 used by Levin et al. [2010] and McMeeking et al. [2009], respectively. A coefficient of determination of 0.94 is observed (Figure 8).

\section{Emission Factors of Levoglucosan}

[47] Levoglucosan (1,6-anhydro- $\beta$-D-glucose), an anhydro sugar and by-product of pyrolysis of cellulose, is a wellestablished biomass burning marker [Shafizadeh and $\mathrm{Fu}$, 1973; Shafizadeh et al., 1979; Shafizadeh, 1984; Simoneit et al., 1999]. Cellulose itself accounts for $40-45 \%$ of wood's dry weight and is composed of linear chains of D-glucose linked by $\beta-1,4$-glycosidic bonds with a degree of polymerization of up to $\sim 15,000$ unit [Pettersen, 1984].

[48] Emission factors of levoglucosan (LG) versus MCE are listed in Table 4. This subset of data encompasses 43 burns. Measured emission factors for levoglucosan vary substantially with fuel type. For the 15 fuel types of this study, $\mathrm{EF}_{\mathrm{LG}}$ varied over 2 orders of magnitude (Table 4). On average, fuels from "Camp Lejeune" emitted the highest amount of levoglucosan per kg fuel burned, while the lowest per mass LG emissions were from the chaparral fuels. The reported values from the current study are within the range reported by Schauer et al. [2001] for residential wood burning, with average EFs of 1375,706 , and $1940 \mathrm{mg} / \mathrm{kg}$ fuel for pine, oak, and eucalyptus,

Table 4. Levoglucosan (LG) Emission Factors (mg/kg Fuel Burned), and Fraction of LG in the PM, Organic Carbon (OC), and Organic Mass $(\mathrm{OM})(\mathrm{Wt} \%)^{\mathrm{a}}$

\begin{tabular}{|c|c|c|c|c|c|}
\hline Fuel type & $\mathrm{EF}_{\mathrm{LG}} \mathrm{mg} / \mathrm{kg}$ & LG/PM $\%$ wt $\%$ & $\mathrm{LG} / \mathrm{OC} \% \mathrm{wt} \%$ & LG/OM\% wt\% & $\mathrm{EC} / \mathrm{TC} \mathrm{wt} \%$ \\
\hline \multicolumn{6}{|c|}{ Southeast } \\
\hline cea & $187 \pm 172$ & $3.19 \pm 2.42$ & $6.24 \pm 3.14$ & $4.1 \pm 2.1$ & $36 \pm 23$ \\
\hline chs & $234 \pm 117$ & $3.03 \pm 1.24$ & $6.44 \pm 3.05$ & $4.2 \pm 2.0$ & $38 \pm 8$ \\
\hline cas & $25.2 \pm 9.3$ & $0.37 \pm 0.17$ & $1.46 \pm 0.13$ & $1.0 \pm 0.1$ & $58 \pm 7$ \\
\hline $\cos$ & $19.7 \pm 6.4$ & $0.31 \pm 0.08$ & $1.53 \pm 0.47$ & $1.0 \pm 0.3$ & $63 \pm 9$ \\
\hline $\operatorname{man}$ & $30.2 \pm 10.3$ & $0.79 \pm 0.21$ & $3.71 \pm 1.13$ & $2.4 \pm 0.7$ & $47 \pm 9$ \\
\hline mch & $79.2 \pm 42.7$ & $1.64 \pm 1.18$ & $6.05 \pm 2.86$ & $4.0 \pm 1.9$ & $44 \pm 18$ \\
\hline Chaparral ave. & $95.9 \pm 35.6$ & $1.56 \pm 0.50$ & $4.24 \pm 0.90$ & $2.8 \pm 0.6$ & $48 \pm 6$ \\
\hline mes & $28.9 \pm 10.9$ & $0.75 \pm 0.08$ & $2.07 \pm 0.37$ & $1.4 \pm 0.2$ & $44 \pm 1$ \\
\hline oas & $29.1 \pm 13.6$ & $1.80 \pm 0.67$ & $4.31 \pm 0.91$ & $2.8 \pm 0.6$ & $52 \pm 8$ \\
\hline oaw & $58.6 \pm 35.1$ & $2.74 \pm 1.12$ & $6.53 \pm 4.12$ & $4.3 \pm 2.7$ & $42 \pm 15$ \\
\hline FHUA ave. & $38.9 \pm 13.1$ & $1.76 \pm 0.44$ & $4.30 \pm 1.41$ & $2.8 \pm 0.9$ & $46 \pm 6$ \\
\hline \multicolumn{6}{|c|}{ Southeast } \\
\hline lit & $1090 \pm 510$ & $5.76 \pm 1.65$ & $5.76 \pm 1.65$ & $3.8 \pm 1.1$ & $10 \pm 6$ \\
\hline 1 year & $888 \pm 522$ & $6.92 \pm 0.33$ & $6.92 \pm 0.33$ & $4.5 \pm 0.2$ & $8 \pm 4$ \\
\hline 2 year & $1270 \pm 540$ & $9.52 \pm 1.04$ & $9.52 \pm 1.04$ & $6.2 \pm 0.7$ & $6 \pm 4$ \\
\hline poc & $208 \pm 142$ & $4.03 \pm 1.11$ & $4.03 \pm 1.11$ & $2.6 \pm 0.7$ & $17 \pm 8$ \\
\hline cuh & $50.2 \pm 6.8$ & 3.02 & 3.02 & $2.0 \pm 0.0$ & 37 \\
\hline uh & $337 \pm 136$ & $5.14 \pm 3.46$ & $5.14 \pm 3.46$ & $3.4 \pm 2.3$ & $32 \pm 9$ \\
\hline Camp Lejeune ave. & $641 \pm 155$ & $5.73 \pm 0.83$ & $5.73 \pm 0.83$ & $3.7 \pm 0.5$ & $18 \pm 3$ \\
\hline
\end{tabular}

${ }^{\mathrm{a}}$ The values represent mean \pm one standard deviation across repeated experiments. 
HOSSEINI ET AL.: PARTICLE EMISSIONS FROM BIOMASS BURNING

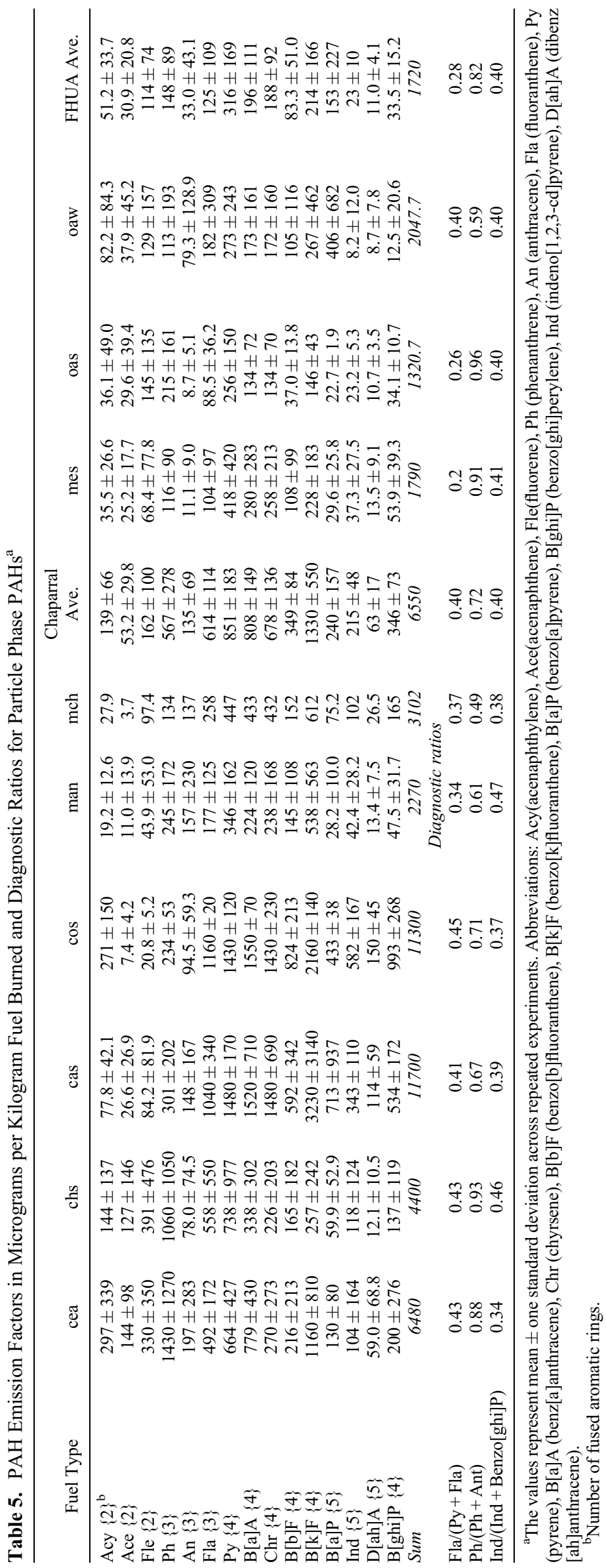




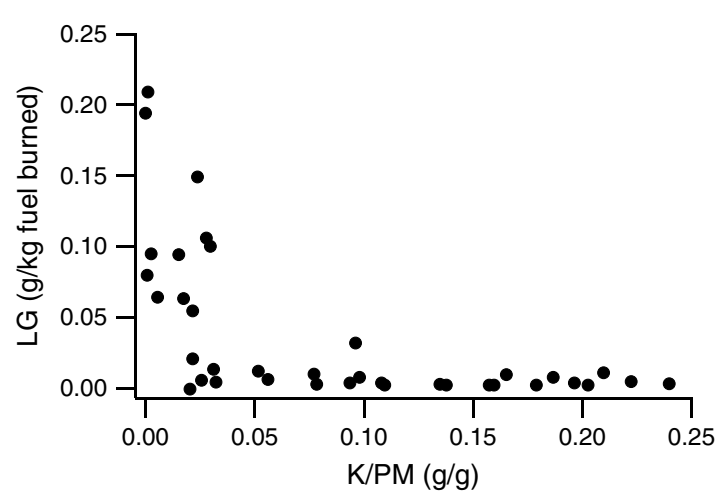

Figure 9. Levoglucosan emission factor ( $\mathrm{g} / \mathrm{kg}$ fuel burned) plotted versus potassium to PM mass ratio $(\mathrm{g} / \mathrm{g})$ for the $\mathrm{SW}$ and SE fuels.

respectively. The $\mathrm{LG} / \mathrm{OC}$ ratios for the three fuel groups were $4.24 \pm 0.90,4.30 \pm 1.41$, and $5.73 \pm 0.83 \mathrm{mg} / \mathrm{g}$ for Chaparral, FHUA, and CL, respectively. Sullivan et al. [2008] during the Fire Laboratory at Missoula Experiments (FLAME) studies measured an average LG/OC value of $70 \mathrm{mg} / \mathrm{g}$ for their 73 burns. Engling et al. [2006] reported values from 36 to $1368 \mu \mathrm{g} / \mathrm{mg}$ OC. The current study values are 2-3 times lower than reported LG/OC ratios for "man" and "chs" [Sullivan et al., 2008] of 8.8-11.4 and $6.3-10.6 \mathrm{mg} / \mathrm{g}$, respectively. In general, fuels from SE emitted more LG per unit weight of fuel compared to the SW fuels. Average MCE alone is unable to account for the differences observed between these studies. Lab experiments suggest that presence of salts, especially salts containing $\mathrm{K}, \mathrm{Li}$, and $\mathrm{Ca}$, significantly reduces $\mathrm{LG}$ pyrolysis yields [Richards and Zheng, 1991; Eom et al., 2012]. Thus, higher K/PM ratios in this study suggest lower $\mathrm{EF}_{\mathrm{LG}}$. As shown in Figure 9, a sharp decrease in LG production is observed at $\mathrm{K} / \mathrm{PM}$ ratio of $\sim 0.03$. Moreover, Ward and Hardy [1991] found that potassium emissions were high during high-temperature flaming phase. Hence, potassium could not be identified as a predictive factor for determining $\mathrm{EF}_{\mathrm{LG}}$ that varied 2 orders of magnitude.

[49] The PM mass fractions of levoglucosan in this study were $1.56( \pm 0.50) \%$ (FHL), 1.76( \pm 0.44$) \%$ (FHUA), and $5.73( \pm 0.83) \%$ (CL) and varied largely between burns from 0.3 for "cos" (lowest) to $9.5 \%$ for "cuh" (highest). SE fuels had the highest levoglucosan PM mass fraction ranging from $3 \%$ (cuh) to $9.5 \%$ (2 year), while SW fuels varied between $0.3 \%$ (cos) and 3.2\% (cea). No correlation between mass fraction of levoglucosan in PM and average MCE was found in contrast to the previous findings of Dhammapala et al. [2007] for wheat and Kentucky bluegrass (only based on three samples).

\section{Emission Factor of Particle-Phase PAHs}

[50] The major emissions of particle-phase PAHs from southwestern fuels are benzo[k] fluoranthene, pyrene, benzo [a] fluoranthene, chrysene, benzo[a] pyrene, fluoranthene, phenanthrene, and fluorene, which contribute approximately $80 \%$ of total particle-phase PAHs for both Chaparral and FHUA groups. Pyrene and benzo[k] fluoranthene alone made up $13-20 \%$ of PAH emissions. Chaparral and FHUA had a mean emission factor of 6550 and $1720 \mu \mathrm{g} / \mathrm{kg}$. The highest observed amount of total PAHs per $\mathrm{kg}$ fuel burned was $11300 \mu \mathrm{g} / \mathrm{kg}$ from "cos" and the lowest was $1300 \mu \mathrm{g} / \mathrm{kg}$ from "oas". In general, Chaparral fuels emitted approximately 4 times higher amount of PAHs than FHUA fuels.

[51] The mass fraction of PAH in the PM varied from $0.03 \%(\mathrm{chs})$ to $0.54 \%(\mathrm{cos})$ and averaged $0.20 \%$ and $0.26 \%$ mass of PM for Chaparral and FHUA fuels, respectively. Despite having less PAH per $\mathrm{kg}$ fuel burned, FHUA resulted in higher fraction of PM in PAHs compared to the Chaparral group.

[52] It has been suggested that the ratio of certain diagnostic ratios for PAHs is useful in determining combustion source [Goncalves et al., 2011; Wang et al., 2009; Alves et al., 2010]. The ratios of Fla/(Py + Fla $)$ and $\mathrm{Ph} /(\mathrm{Ph}+\mathrm{Ant})$ as suggested by Wang et al. [2009] and Ind/(Ind + Benzo [ghi]P) by Goncalves et al. [2011] are shown in the bottom of Table 5 for all the fuel types and the two fuel groups. The ratio $\mathrm{Fla} /(\mathrm{Py}+\mathrm{Fla})$ was $0.40 \pm 0.04$ for Chaparral group and $0.20 \pm 0.10$ for FHUA group. The FHUA ratios are similar to those reported from combustion of cereal straw (0.50-0.53) [Hays et al., 2005], shrubs (0.54-0.60) [Wang et al., 2009], and agricultural residue (0.46-0.63) [Goncalves et al., 2011]. The "mes" and "oas" did not fall within the range of suggested ratios for the ratio of Fla/ $(\mathrm{Py}+\mathrm{Fla})$. The $\mathrm{Ph} /(\mathrm{Ph}+\mathrm{Ant})$ ratio averaged $0.72 \pm 0.17$ (except for "mch") and was consistent with the range reported by above mentioned studies. The "mes" and "oas" from FHUA significantly have higher $\mathrm{Ph} /(\mathrm{Ph}+\mathrm{Ant})$ ratios $(\sim 0.9)$ close to the values seen from cooking emissions/engine exhaust [He et al., 2004; Rogge et al., 1993; Schauer et al., 1999], which in addition to a differing fuel type, the disparity might be due to the high MCE values. Most of the studies used by Wang et al. [2009] are combustion processes involving mostly smoldering (based on small EC/TC ratios). Therefore, the range of suggested diagnostic ratios might not be robust due to the overlap of suggested ranges between different emission sources [Goncalves et al., 2011] and also not covering the wider range of possible MCE values (e.g., higher MCEs were observed in the current study). Ind/ (Ind + Benzo[ghi]P) was $0.40 \pm 0.04$ for both fuel groups. Our data are close to the lower end of evaluated values from the study of Hays et al. [2005] for cereal straw. Chinese cooking [He et al., 2004] and automobile and trucks [Rogge et al., 1993] have ratios of 0.19 and 0.04-0.09, respectively.

\section{Conclusions}

[53] We report detailed particle-phase emission measurements from combustion of different vegetation types typically managed with fire on military bases in the southwest and southeast U.S. Since these fuels burn periodically (prescribed or wildfire), the results of this study will help to better understand and manage air quality impacts in neighboring areas. Emission factors for numerous species are provided as a function of MCE. At a certain FM, all observed average MCEs were limited between two heading and backing fire average MCEs. Due to lack of sufficient data, it was impossible to model the fire behavior; more effort is needed for characterizing the MCE. 
[54] On average, the SE fuels emitted more PM mass (10.8 g/kg fuel burned) compared to SW fuels $(3.83 \mathrm{~g} / \mathrm{kg}$ fuel burned) consistent with lower average MCE for SE fuels. No regional trend was observed after accounting for MCE. Some of the observed differences between field and lab results for similar MCE may be attributable to the smoke temperature, fuel bed differences as discussed in more detail elsewhere [Yokelson et al., 2013], and also time scale of the MCE measurement (field is on order of hours, laboratory on order of a few minutes). Due to the nonlinear emissions behavior with MCE, comparison of fire-integrated values from lab and field studies might result in unexpected and unexplainable differences.

[55] The SE and SW fuels showed large regional dependency in their emission factors for particle inorganics. The PM mass fraction of chlorine and potassium in the SW fuels was on the high end of values reported in the literature. Any correlation between these emission rates and the average $\backslash \mathrm{MCE}$ was masked by large variations due to fuel composition. Chlorine alone accounted for $0.4-24.5 \%$ of the watersoluble mass fraction. Sulfate correlated weakly with the average MCE. Comparison of XRF and IC results indicates the vast majority $(\sim 88 \%)$ of sulfur and potassium are present as $\mathrm{SO}_{4}{ }^{2-}$ and $\mathrm{K}^{+}$, respectively. Inorganic species contributed 9-62\% and $2-15 \%$ of PM mass for SW and SE fuels, respectively. No correlation was observed between average MCE and calcium, ammonium, bromide, and nitrate. Unlike the current study that considers average emissions for duration of a burn, studies such as Lee et al. [2010] investigated transient fire emissions using high-resolution time-of-flight aerosol mass spectrometer (HR-TOF-AMS) and found strong change in potassium emissions between the flaming and smoldering stages of combustion.

[56] Levoglucosan/OC ratios were observed to be a function of the fuel type with little to no correlation with the average MCE. Finally, the emission factor of 15 PAHs totaled $1-11 \mathrm{mg} / \mathrm{kg}$ burned for SW. Eighty percent of measured particle phase PAHs were attributed to benzo[k] fluoranthene, pyrene, benzo[a] fluoranthene, chrysene, benzo[a] pyrene, fluoranthene, phenanthrene, and fluorene. Pyrene and benzo[k] fluoranthene constituted 13-20\% of particle-phase PAHs emissions. Previously published PAH diagnostic ratios were not observed to be good markers for our biomass burning samples.

[57] Acknowledgments. This work was supported by the Department of Defense's Strategic Environmental Research and Development Program (SERDP), resources conservation projects RC-1648 and RC-1649 and we thank our sponsors for their support.

\section{References}

Akagi, S. K., R. J. Yokelson, C. Wiedinmyer, M. J. Alvarado, J. S. Reid, T. Karl, J. D. Crounse, and P. O. Wennberg (2011), Emission factors for open and domestic biomass burning for use in atmospheric models, Atmos. Chem. Phys., 11, 4039, doi:10.5194/acp-11-4039-2011.

Akagi, S. K., et al. (2012), Evolution of trace gases and particles emitted by a chaparral fire in California, Atmos. Chem. Phys., 12, 1397, doi:10.5194/ acp-12-1397-2012.

Albini, F. (1976), Estimating wildfire behavior and effects, USDA Forest Service General Technical Report INT, 30.

Alves, C. A., C. Gonçalves, M. Evtyugina, C. A. Pio, F. Mirante, and H. Puxbaum (2010), Particulate organic compounds emitted from experimental wildland fires in a Mediterranean ecosystem, Atmos. Environ., 44 2750-2759.

Anderson, K. A. (1996), Micro-digestion and ICP-AES analysis for the determination of macro and micro elements in plant tissues, At. Spectrosc., $17(1), 30$.
Andreae, M., and P. Merlet (2001), Emission of trace gases and aerosols from biomass burning, Global Biogeochem. Cycles, 15(4), 955.

Birch, M., and R. Cary (1996), Elemental carbon-based method for monitoring occupational exposures to particulate diesel exhaust, Aerosol Sci. Technol., 25(3), 221.

Blackmarr, W. H., W. B., Flanner (1975), Moisture variation in selected pocosin shrubs of eastern North Carolina (Research Paper No. SE-124). USDA Forest Service, Southeastern Forest Experiment Station, Asheville, NC.

Burling, I., et al. (2010), Laboratory measurements of trace gas emissions from biomass burning of fuel types from the southeastern and southwestern United States, Atmos. Chem. Phys., 10, 11115.

Burling, I., R. Yokelson, S. Akagi, S. Urbanski, C. Wold, D. Griffith, T. Johnson, J. Reardon, and D. Weise (2011), Airborne and groundbased measurements of the trace gases and particles emitted by prescribed fires in the United States, Atmos. Chem. Phys., 11, 12197.

California Air Resources Board (2011), Standard operating procedure no. MLD 142, Procedure for the Analysis of Particulate Anions and Cations in Motor Vehicle Exhaust by Ion Chromatography, El Monte, California, revision 2.0.

Chakrabarty, R. K., H. Moosmüller, M. A. Garro, W. P. Arnott, J. Walker, R. A. Susott, R. E. Babbitt, C. E. Wold, E. N. Lincoln, and W. M. Hao (2006), Emissions from the laboratory combustion of wildland fuels: Particle morphology and size, J. Geophys. Res., 111, D07204, doi:10.1029/2005JD006659.

Chandler, C., P. Cheney, P. Thomas, L. Trabaud, and D. Williams (1983), Fire in forestry, in Forest Fire Behavior and Effects., vol. 1, p. 450, John Wiley and Sons, New York.

Chang-Graham, A. L., L. T. M. Profeta, T. J. Johnson, R. J. Yokelson, A. Laskin, and J. Laskin (2011), A case study of water soluble metal containing organic constituents of biomass burning aerosol, Environ. Sci. Technol., 45, 1257, doi:10.1021/es103010j.

Chen, L. W. A., H. Moosmuller, W. P. Arnott, J. C. Chow, and J. G. Watson (2006), Particle emissions from laboratory combustion of wildland fuels: In situ optical and mass measurements, Geophys. Res. Lett., 33, L04803, doi:10.1029/2005GL024838.

Chen, L. W. A., H. Moosmüller, W. P. Arnott, J. C. Chow, J. G. Watson, R. A. Susott, R. E. Babbitt, C. E. Wold, E. N. Lincoln, and W. M. Hao (2007), Emissions from laboratory combustion of wildland fuels: Emission factors and source profiles, Environ. Sci. Technol., 41(12), 4317, doi:10.1021/es062364i.

Chen, L.-W. A., P. Verburg, A. Shackelford, D. Zhu, R. Susfalk, J. C. Chow, and J. G. Watson (2010), Moisture effects on carbon and nitrogen emission from burning of wildland biomass, Atmos. Chem. Phys., 10, 6617, doi:10.5194/acp-10-6617-2010.

Chow, J. C., J. G. Watson, D. H. Lowenthal, L. W. A. Chen, and K. L. Magliano (2006), Particulate carbon measurements in California's San Joaquin Valley, Chemosphere, 62(3), 337.

Christian, T., B. Kleiss, R. Yokelson, R. Holzinger, P. Crutzen, W. Hao, B. Saharjo, and D. Ward (2003), Comprehensive laboratory measurements of biomass-burning emissions: 1. Emissions from Indonesian, African, and other fuels, J. Geophys. Res., 108(D23), 4719, doi:10.1029/ 2003JD003704.

Christian, T. J., B. Kleiss, R. J. Yokelson, R. Holzinger, P. J. Crutzen, W. M. Hao, T. Shirai, and D. R. Blake (2004), Comprehensive laboratory measurements of biomass-burning emissions: 2 . First intercomparison of open-path FTIR, PTR-MS, and GC-MS/FID/ECD, J. Geophys. Res., 109, D02311, doi:10.1029/2003JD003874.

Code of Federal Regulations (2005), 40CFR Part 1065, 2005, Washington, DC.

Countryman, C. M., and W. A. Dean (1979), Measuring moisture content in living chaparral: A field user's manual, Gen. Tech. Report PSW-36, Pac. Southwest For. and Range Exp. Stn., For. Serv., U.S. Dep. of Agric., Berkeley, Calif.

Crutzen, P. J., and M. O. Andreae (1990), Biomass burning in the tropics: Impact on atmospheric chemistry and biogeochemical cycles, Science, $250(4988), 1669$.

Dhammapala, R., C. Claiborn, J. Jimenez, J. Corkill, B. Gullett, C. Simpson, and M. Paulsen (2007), Emission factors of PAHs, methoxyphenols, levoglucosan, elemental carbon and organic carbon from simulated wheat and Kentucky bluegrass stubble burns, Atmos. Environ., 41(12), 2660, doi:10.1016/j.atmosenv.2006.11.023.

Engling, G., et al. (2006), Determination of levoglucosan in biomass combustion aerosol by high-performance anion-exchange chromatography with pulsed amperometric detection, Atmos. Environ., 40, 299, doi:10.1016/j.atmosenv.2005.12.069.

Eom, I.-Y., J.-Y. Kim, T. S. Kim, S.-M. Lee, D. Choi, I.-G. Choi, and J.-W. Choi (2012), Effect of essential inorganic metals on primary thermal degradation of lignocellulosic biomass, Bioresour. Technol., 104(0), 687, doi:10.1016/j.biortech.2011.10.035. 
Fenn, M. (1991), Increased site fertility and litter decomposition rate in high-pollution sites in the San Bernardino Mountains, For. Sci., 37(4), 1163 (19).

Fishman, J., K. Fakhruzzaman, B. Cros, and D. Nganga (1991) Identification of widespread pollution in the southern hemisphere deduced from satellite analyses, Science, 252(5013), 1693.

Goncalves, C., M. Evtyugina, C. Alves, C. Monteiro, C. Pio, and M. Tome (2011), Organic particulate emissions from field burning of garden and agriculture residues, Atmos. Res., 101(2011), 666.

Hardy, C. C., S. G. Conard, J. C. Regelbrugge, and D. R. Teesdale (1996), Smoke emissions from prescribed burning of southern California chaparral, US Department of Agriculture, Forest Service, Pacific Northwest Research Station.

Hays, M. D., C. D. Geron, K. J. Linna, N. D. Smith, and J. J. Schauer (2002), Speciation of gas-phase and fine particle emissions from burning of foliar fuels, Environ. Sci. Technol., 36(11), 2281, doi:10.1021/es0111683.

Hays, M., P. Fine, C. Geron, M. Kleeman, and B. Gullett (2005), Open burning of agricultural biomass: Physical and chemical properties of particlephase emissions, Atmos. Environ., 39(36), 6747.

Haywood, J., S. Osborne, P. Francis, A. Keil, P. Formenti, M. Andreae, and P. Kaye (2003), The mean physical and optical properties of regional haze dominated by biomass burning aerosol measured from the C-130 aircraft during SAFARI 2000, J. Geophys. Res., 108(D13), 8473, doi:10.1029/2002JD002226.

He, L., M. Hu, X. Huang, B. Yu, Y. Zhang, and D. Liu (2004), Measurement of emissions of fine particulate organic matter from Chinese cooking, Atmos. Environ., 38(38), 6557.

Hobbs, P., J. Reid, R. Kotchenruther, R. Ferek, and R. Weiss (1997), Direct radiative forcing by smoke from biomass burning, Science, 275(5307), 1777.

Hosseini, S., Q. Li, D. Cocker, D. Weise, A. Miller, M. Shrivastava, J. Miller, S. Mahalingam, M. Princevac, and H. Jung (2010), Particle size distributions from laboratory-scale biomass fires using fast response instruments, Atmos. Chem. Phys., 10, 8065.

Kaufman, Y., and R. Fraser (1997), The effect of smoke particles on clouds and climate forcing, Science, 277(5332), 1636.

Keeley, J. E. (2001), Fire and invasive species in Mediterranean-climate ecosystems of California, in Proceedings of the Invasive Species Workshop: The Role of Fire in the Control and Spread of Invasive Species, edited by K. E. M. Galley and T. P. Wilson, pp., 81, Tall Timbers Research Station Misc. Publ. No. 11, Tallahassee.

Keene, W. C., J. M. Lobert, P. J. Crutzen, J. R. Maben, D. H. Scharffe, T. Landmann, C. Hély, and C. Brain (2006), Emissions of major gaseous and particulate species during experimental burns of southern African biomass, J. Geophys. Res., 111, D04301, doi:10.1029/2005JD006319.

Lee, S., K. Baumann, J. J. Schauer, R. J. Sheesley, L. P. Naeher, S. Meinardi, D. B. Blake, E. S. Edgerton, A. G. Russell, and M. Clements (2005), Gaseous and particulate emissions from prescribed burning in Georgia, Environ. Sci. Technol., 39, 9049.

Lee, T., A. P. Sullivan, L. Mack, J. L. Jimenez, S. M. Kreidenweis, T. B. Onasch, and J. L. Collett Jr (2010), Chemical smoke marker emissions during flaming and smoldering phases of laboratory open burning of wildland fuels, Aerosol Sci. Technol., 44(9).

Levin, E., et al. (2010), Biomass burning smoke aerosol properties measured during Fire Laboratory at Missoula Experiments (FLAME), J. Geophys. Res., 115, D18210, doi:10.1029/2009JD013601.

Lobert, J. M., D. H. Scharffe, W. M. Hao, T. A. Kuhlbusch, R. Seuwen, P. Warneck, and P. J. Crutzen (1991), Experimental evaluation of biomass burning emissions: Nitrogen and carbon containing compounds, in Global Biomass Burning: Atmospheric, Climatic, and Biospheric Implications, edited by J. S. Levine, 289 pp., MIT Press, Cambridge,Mass.

Mamakos, A., L. Ntziachristos, and Z. Samaras (2006), Evaluation of the Dekati mass monitor for the measurement of exhaust particle mass emissions, Environ. Sci. Technol., 40(15), 4739.

Materna, B. L., J. R. Jones, P. M. Sutton, N. Rothman, and R. J. Harrison (1992), Occupational exposures in California wildland fire fighting, $\mathrm{Am}$. Ind. Hyg. Assoc. J., 53(1), 69.

McGeehan, S., and D. Naylor (1998), Automated instrumental analysis of carbon and nitrogen in plant and soil samples 1, Comm. Soil Sci. Plant Anal., 19(4), 493.

McKenzie, L. M., D. E. Ward, and W. M. Hao (1996), Chlorine and bromine in the biomass of tropical and temperate ecosystems, in Biomass Burning and Global Change, Vol. 1: Remote Sensing, Modeling and Inventory Development, and Biomass Burning in Africa, edited by J. S. Levine, pp., 241-248, MIT press, MA.

McMeeking, G., S. Kreidenweis, S. Baker, C. Carrico, J. Chow, J. Collett, Jr, W. Hao, A. Holden, T. Kirchstetter, and W. Malm (2009), Emissions of trace gases and aerosols during the open combustion of biomass in the laboratory, J. Geophys. Res., 114, D19210, doi:10.1029/2009JD011836.

Muhle, J., T. J. Lueker, Y. Su, B. R. Miller, K. A. Prather, and R. F. Weiss (2007), Trace gas and particulate emissions from the 2003 southern
California wildfires, J. Geophys. Res., 112, D03307, doi:10.1029/ 2006JD007350.

Na, K., A. A. Sawant, C. Song, and D. R. Cocker (2004), Primary and secondary carbonaceous species in the atmosphere of Western Riverside County, California, Atmos. Environ., 38(9), 1345.

Narayan, C., P. M. Fernandes, J. van Brusselen, and A. Schuck (2007), Potential for $\mathrm{CO}_{2}$ emissions mitigation in Europe through prescribed burning in the context of the Kyoto Protocol, For. Ecol. Manage., 251(3), 164

Pettersen, R. (1984), The chemical composition of wood, Adv. Chem. Ser., 207, 57.

Pitchford, M., W. Malm, B. Schichtel, N. Kumar, D. Lowenthal, and J. Hand (2007), Revised algorithm for estimating light extinction from improve particle speciation data, J. Air Waste Manage. Assoc., 57(11), 1326.

Pope, C., III, M. Ezzati, and D. Dockery (2009), Fine-particulate air pollution and life expectancy in the United States, N. Engl. J. Med., 360(4), 376.

Qi, L., S. Hosseini, H. Jung, R. Yokelson, D. Weise, D. Cocker, and Y. Huang (2012), Chemical characterization of particle emissions from controlled burns of biomass fuels using a high resolution time-of-flight aerosol mass spectrometer, Atmos. Chem. Phys. Discuss., 12, 8397, doi:10.5194/acpd-12-8397-2012.

Ramdahl, T., and G. Becher (1982), Characterization of polynuclear aromatic hydrocarbon derivatives in emissions from wood and cereal straw combustion, Anal. Chim. Acta, 144, 83.

Reid, J. S., P. V. Hobbs, R. J. Ferek, D. R. Blake, J. V. Martins, M. R. Dunlap, and C. Liousse (1998), Physical, chemical, and optical properties of regiona hazes dominated by smoke in Brazil, J. Geophys. Res., 103, 32,059.

Reid, J., R. Koppmann, T. Eck, and D. Eleuterio (2005), A review of biomass burning emissions. Part II: Intensive physical properties of biomass burning particles, Atmos. Chem. Phys, 5(3), 799

Reinhardt, T. E., and R. D. Ottmar (1997). Smoke exposure among wildland firefighters: A review and discussion of current literature, Portland, OR: US Department of Agriculture, Forest Service, Pacific Northwest Research Station.

Reinhardt, T. E., and R. D. Ottmar (2004), Baseline measurements of smoke exposure among wildland firefighters, J. Occup. Environ. Hyg., 1(9), 593.

Richards, G. N., and G. Zheng (1991), Influence of metal ions and of salts on products from pyrolysis of wood: Applications to thermochemical processing of newsprint and biomass, J. Anal. Appl. Pyrolysis, 21(1-2), 133, doi:10.1016/0165-2370(91)80021-y.

Roberts, R. A., and J. Corkill (1998), Grass seed field smoke and its impact on respiratory health, J. Environ. Health, 60(10), 15

Roberts, J., et al. (2010), Measurement of HONO, HNCO, and other inorganic acids by negative-ion proton-transfer chemical-ionization mass spectrometry (NI-PT-CIMS): Application to biomass burning emissions, Atmos. Meas. Technol., 3, 981.

Roberts, J. M., P. R. Veres, A. K. Cochran, C. Warneke, I. R. Burling, R. J. Yokelson, B. Lerner, J. S. Holloway, R. Fall, and J. de Gouw (2011), Isocyanic acid in the atmosphere: Sources, concentration and sinks, and potential health effects, PNAS 2011108 (22) 8966 doi: 10.1073/pnas. 1103352108 .

Rogge, W., L. Hildemann, M. Mazurek, G. Cass, and B. Simoneit (1993), Sources of fine organic aerosol. 2. Noncatalyst and catalyst-equipped automobiles and heavy-duty diesel trucks, Environ. Sci. Technol., 27(4), 636

Schauer, J., M. Kleeman, G. Cass, and B. Simoneit (1999), Measurement of emissions from air pollution sources. $1 . \mathrm{C}_{1}$ through $\mathrm{C}_{29}$ organic compounds from meat charbroiling, Environ. Sci. Technol., 33(10), 1566.

Schauer, J. J., M. J. Kleeman, G. R. Cass, and B. R. T. Simoneit (2001), Measurement of emissions from air pollution sources. 3. C1-C29 organic compounds from fireplace combustion of wood, Environ. Sci. Technol., $35(9), 1716$

Schultz, M. G., A. Heil, J. J. Hoelzemann, A. Spessa, K. Thonicke, J. G. Goldammer, A. C. Held, J. M. C. Pereira, and M. van het Bolscher (2008), Global wildland fire emissions from 1960 to 2000, Global Biogeochem. Cycles, 22, GB2002, doi:10.1029/2007GB003031.

Shafizadeh, F. (1984), The chemistry of pyrolysis and combustion, in The Chemistry of Solid Wood, edited by R. Rowell, pp. 489-529, American Chemical Society, Washington, D.C

Shafizadeh, F., and Y. Fu (1973), Pyrolysis of cellulose, Carbohydr. Res. 29(1), 113.

Shafizadeh, F., R. Furneaux, T. Cochran, J. Scholl, and Y. Sakai (1979), Production of levoglucosan and glucose from pyrolysis of cellulosic materials, J. Appl. Polym. Sci., 23(12), 3525

Simoneit, B., J. Schauer, C. Nolte, D. Oros, V. Elias, M. Fraser, W. Rogge and G. Cass (1999), Levoglucosan, a tracer for cellulose in biomass burning and atmospheric particles, Atmos. Environ., 33(2), 173

Sinha, P., P. Hobbs, R. Yokelson, I. Bertschi, D. Blake, I. Simpson, S. Gao, T. Kirchstetter, and T. Novakov (2003), Emissions of trace gases and particles from savanna fires in Southern Africa, J. Geophys. Res., 108(D13), 8487, doi:10.1029/2002JD002325. 
Sinha, P., P. Hobbs, R. Yokelson, D. Blake, S. Gao, and T. Kirchstetter (2004), Emissions from miombo woodland and dambo grassland savanna fires, J. Geophys. Res., 109, D11305, doi:10.1029/2004JD004521.

Sullivan, A., A. Holden, L. Patterson, G. McMeeking, S. Kreidenweis, W. Malm, W. Hao, C. Wold, and J. Collett, Jr. (2008), A method for smoke marker measurements and its potential application for determining the contribution of biomass burning from wildfires and prescribed fires to ambient PM2. 5 organic carbon, J. Geophys. Res., 113, D22302, doi:10.1029/2008JD010216.

Urbanski, S. P., W. M. Hao, and S. Baker (2009), Chemical composition of wildland fire emissions, in Wildland Fires and Air Pollution. Developments in Environmental Science, 8, edited by A. Bytnerowicz, et al., 79-107, Elsevier, Amsterdam.

Veres, P., J. Roberts, I. Burling, C. Warneke, J. de Gouw, and R. Yokelson (2010), Measurements of gas-phase inorganic and organic acids from biomass fires by negative-ion proton-transfer chemical-ionization mass spectrometry, J. Geophys. Res., 115, D23302, doi:10.1029/2010JD014033.

Wang, Z., X. Bi, G. Sheng, and J. Fu (2009), Characterization of organic compounds and molecular tracers from biomass burning smoke in South China I: Broad-leaf trees and shrubs, Atmos. Environ., 43(19), 3096.

Ward, D. (1998), Smoke From Wildland Fires. Health Guidelines for Vegetation Fire Events, 6 pp., United Nations Environment Programme (UNEP), Lima, Peru.

Ward, D., and C. Hardy (1991), Smoke emissions from wildland fires, Environ. Int., 17(2-3), 117.

Ward, D. E., and L. Radke (1993), Chapter 4: Emission measurements from vegetation fires: A comparative evaluation of methods and results, in Fire in the Environment: The Ecological, Atmospheric, and Climatic Importance of Vegetation Fires, edited by P. J. Crutzen and J. G. Goldammer, John Wiley \& Sons.

Ward, D. E., R. M. Nelson, and D. F. Adams (1979), Forest fire smoke plume documentation, Proceedings of the 72nd Annual Meeting, Air Pollution Control Association, No. 79-6.3, 24-29 June, Cincinnati, Ohio.
Weise, D., D. Ward, T. Paysen, and A. Koonce (1991), Burning California chaparral-An exploratory study of some common shrubs and their combustion characteristics, Int. J. Wildland Fire, 1(3), 153.

Wiedinmyer, C., and M. Hurteau (2010), Prescribed fire as a means of reducing forest carbon emissions in the western united states, Environ. Sci. Technol., 44(6), 1926.

Wiedinmyer, C., B. Quayle, C. Geron, A. Belote, D. McKenzie, X. Y. Zhang, S. O'Neill, and K. K. Wynne (2006), Estimating emissions from fires in North America for air quality modeling, Atmos. Environ., 40(19), 3419, doi:10.1016/j.atmosenv.2006.02.010.

Yokelson, R. J., D. W. Griffith, and D. E. Ward (1996), Open-path Fourier transform infrared studies of large-scale laboratory biomass fires, $J$. Geophys. Res., 101(D15), 21,067-21,080, doi:10.1029/96JD01800.

Yokelson, R. J., J. G. Goode, D. E. Ward, R. A. Susott, R. E. Babbitt, D. D. Wade, I. Bertschi, D. W. T. Griffith, and W. M. Hao (1999), Emissions of formaldehyde, acetic acid, methanol, and other trace gases from biomass fires in North Carolina measured by airborne Fourier transform infrared spectroscopy, J. Geophys. Res., 104, 30,109-30,125, doi:10.1029/1999JD900817.

Yokelson, R., A. Clarke, A. Weinheimer, D. Knapp, D. Montzka, J. Holloway, P. Weibring, F. Flocke, and W. Zheng (2009), Emissions from biomass burning in the Yucatan, Atmos. Chem. Phys., 9(15), 5785.

Yokelson, R. J., I. R. Burling, S. P. Urbanski, E. L. Atlas, K. Adachi, P. R. Buseck, C. Wiedinmyer, S. K. Akagi, D. W. Toohey, and C. E. Wold (2011), Trace gas and particle emissions from open biomass burning in Mexico, Atmos. Chem. Phys., 11, 6787, doi:10.5194/acp-116787-2011.

Yokelson, R. J., et al. (2013), Coupling field and laboratory measurements to estimate the emission factors of identified and unidentified trace gases for prescribed fires, Atmos. Chem. Phys., 13, 89, doi:10.5194/ acp-13-89-2013 